NBER WORKING PAPER SERIES

\title{
DO GOVERNMENT AUDITS REDUCE CORRUPTION? ESTIMATING THE IMPACTS OF EXPOSING CORRUPT POLITICIANS
}

\author{
Eric Avis \\ Claudio Ferraz \\ Frederico Finan \\ Working Paper 22443 \\ http://www.nber.org/papers/w22443 \\ NATIONAL BUREAU OF ECONOMIC RESEARCH \\ 1050 Massachusetts Avenue \\ Cambridge, MA 02138 \\ July 2016
}

We thank Daron Acemoglu, Steve Coate, Stephan Litschig, Paul Novosad, Stephane Straub, and Torsten Persson, and seminar participants at the Barcelona Summer Forum, Chicago, Dartmouth, Harvard, LSE, Princeton, Toulouse, Warwick, and Wharton for helpful discussions and comments. We are also grateful to the Controladoria-Geral da União (CGU) for providing us with the audits data. The views expressed herein are those of the authors and do not necessarily reflect the views of the National Bureau of Economic Research.

NBER working papers are circulated for discussion and comment purposes. They have not been peer-reviewed or been subject to the review by the NBER Board of Directors that accompanies official NBER publications.

(C) 2016 by Eric Avis, Claudio Ferraz, and Frederico Finan. All rights reserved. Short sections of text, not to exceed two paragraphs, may be quoted without explicit permission provided that full credit, including $\odot$ notice, is given to the source. 
Do Government Audits Reduce Corruption? Estimating the Impacts of Exposing Corrupt Politicians Eric Avis, Claudio Ferraz, and Frederico Finan

NBER Working Paper No. 22443

July 2016

JEL No. H41,H77,H83,K42,O1,O38,O43,O54

\begin{abstract}
$\underline{\text { ABSTRACT }}$
Political corruption is considered a major impediment to economic development, and yet it remains pervasive throughout the world. This paper examines the extent to which government audits of public resources can reduce corruption by enhancing political and judiciary accountability. We do so in the context of Brazil's anti-corruption program, which randomly audits municipalities for their use of federal funds. We find that being audited in the past reduces future corruption by 8 percent, while also increasing the likelihood of experiencing a subsequent legal action by 20 percent. We interpret these reduced-form findings through a political agency model, which we structurally estimate. Based on our estimated model, the reduction in corruption comes mostly from the audits increasing the perceived threat of the non-electoral costs of engaging in corruption.
\end{abstract}

Eric Avis

University of California at Berkeley

eavis@berkeley.edu

Claudio Ferraz

Department of Economics

PUC-Rio

Rio de Janeiro, RJ, 22453-900

Brazil

cferraz@econ.puc-rio.br
Frederico Finan

Department of Economics

University of California

508-1 Evans Hall \#3880

Berkeley, CA 94720-3880

and NBER

ffinan@econ.berkeley.edu 


\section{Introduction}

Politicians throughout the world embezzle billions of dollars each year, and in so doing induce the misallocation of resources, foster distrust in leaders, and threaten the very pillars of democracy (Rose-Ackerman (1999)). And while the adverse consequences of corruption have been long recognized, there is little consensus over how best to fight it. ${ }^{1}$ One point of growing emphasis in the literature has been the importance of political institutions that constrain rent-seeking, and in particular the role of elections in selecting and disciplining politicians. ${ }^{2}$ Another strand of the literature has instead focused on the effectiveness of a country's judicial and prosecutorial institutions: If severe enough, the legal consequences of rent extraction should also discipline politicians (Becker (1968) and Becker and Stigler (1974)).

Although a successful anti-corruption strategy is likely to include reforms to strengthen both sectors, the efficacy of these institutions ultimately depends on a government's ability to detect corruption in the first place. This has led several countries to adopt audit programs aimed at uncovering the misuse of public resources, which not only increase the probability of detecting wrongdoing, but also provide the requisite information to both voters, as well as prosecutors, to hold politicians accountable for malfeasance.

In this paper, we investigate the role government audits play in reducing political corruption among local government through the promotion of electoral and judicial accountability. We do so in the context of Brazil's anti-corruption program which began in 2003 and has since audited 1,949 municipalities at random, many of which multiple times. Consequently, for several rounds of later audits, we are able to compare the corruption levels discovered among the municipalities that are being audited for the first time (control group) to the corruption levels of municipalities that had also been audited in the past (treatment group). Because municipalities are selected at random, this simple comparison estimates the causal effects of a past audit on future corruption levels, in a setting in which both groups face the same ex-ante probability of being audited. As documented for the case of tax evasion, past audits can affect future corruption levels by changing an individual's perceived probability of detection. ${ }^{3}$

\footnotetext{
${ }^{1}$ See for example Fisman et al. (2014) for estimates of wealth accumulation of politicians in India and Pande (2008) and Olken and Pande (2012) for overviews of the economics of corruption in developing countries.

${ }^{2}$ See Besley (2007) and Ashworth (2012) for reviews of agency models and Ferraz and Finan (2008), Ferraz and Finan (2011), Bobonis et al. (2015) for evidence on how elections can discipline politicians.

${ }^{3}$ Kleven et al. (2011) conduct a field experiment on tax enforcement in Denmark, in which tax filers were randomly selected to be audited. In the following year, a threat-of-audit letters were sent to both groups. As in our study, they find that prior audits have a significant effect (and even larger effect than the threat of an audit) on self-reported income.
} 
We find that corruption levels are approximately 8 percent lower among treated municipalities compared to control municipalities, suggesting that audits do affect the perceived detection probability. Consistent with this interpretation, we find that past audits also affect the corruption levels of neighboring municipalities with local media, which are the places most likely to learn about the outcome of another municipality's audit. For these municipalities, having an additional neighbor audited leads them to reduce their own corruption by 7.5 percent. The average municipality in our sample receives $\mathrm{R} \$ 15,000,000$ in federal transfers per year. Based on our estimates of a random sample of audit reports, 30 percent of the funds audited were found to be diverted, implying that the audits reduced corruption by $\mathrm{R} \$ 567,135$ per year per municipality, once we account for the spillover effects.

We interpret the main findings in the context of a simple model of political accountability, which we then subsequently estimate. Based on our model, there are several reasons why the audits may have led to a reduction in local corruption. First, the audits may have reduced corruption through a political selection effect. As documented in Ferraz and Finan (2008), in places that were audited before the election, voters were able to reward good and punish bad incumbents who were up for re-election. Second, the audits may have led to a stronger electoral disciplining effect. If an audit increases a mayor's subjective probability of being detected and he has re-election concerns, then he has less incentive to engage in corruption. Of course, an unfavorable audit can also trigger other non-electoral costs, such as judicial punishment or reputation costs. So even if a mayor does not have re-election concerns, an update in the probability of being found to be corrupt can lead to a non-electoral disciplining effect. Finally, the audits may have also affected the political environment more generally by inducing a better selection of candidates (i.e. an entry effect). ${ }^{4}$

We investigate these mechanisms both in the reduced-form and structurally. Despite the different assumptions underlying these two approaches, we find consistent evidence for a non-electoral disciplining effect, with minimal support for the other channels. Our model estimates suggest the disciplining effects from non-electoral costs can explain 94 percent of the reduction in local corruption. Consistent with this result, we also document that an audit can generate substantial non-electoral costs. Using data on anti-corruption crackdowns and federal convictions, we find that having been audited increases the likelihood of incurring a legal action by 20 percent.

Given our findings, we then use our structural estimates to explore three counterfactual policies

\footnotetext{
${ }^{4}$ Outside of the context of our model, there are two other possible explanations for the reduction in the corruption. One interpretation for our findings is that the audits teach mayors to better hide corruption. The other interpretation is that the federal government offered fewer transfers in response to an audit, and thus made it harder for future mayors to engage in corruption. We test for both of these channels and do not find support for these interpretations.
} 
aimed at further reducing corruption. First, we simulate changes in the probability that rents are detected by the electorate, which would be the case if the audit program increased the frequency of audit lotteries or the number of municipalities audited in each lottery. Second, we simulate changes to non-electoral costs. In practice, non-electoral costs could be increased if, for example, conviction rates conditional on corruption uncovered in audits increased. Finally, we simulate increases to the value of holding office, which would be the case if mayoral wages were to increase.

Based on these simulations, a policy aimed at increasing the non-electoral costs of corruption would be the most effective. Our estimated model implies that a 5 percent increase in the non-electoral costs of corruption would decrease corruption by approximately 20 percent. In contrast, given the uncertainty associated with electoral punishment, a 5 percentage point increase in the probability that corruption is detected will only lead to a 9 percent reduction in corruption for first-term mayors and a 1 percent reduction for second-term mayors. According to our estimates, an increase to the value of holding office would be the least effective at reducing corruption, especially in an environment in which accountability is either weak or absent. An increase in the value of holding office by the average rents stolen would only reduce corruption by 3 percent for first-term mayors.

Our findings are related to three broad literatures. First, our study contributes to a large literature on the determinants of political corruption and the design of policies aimed at curbing corruption. For example, Bobonis et al. (2015) find that audit reports in Puerto Rico released just prior to the election (compared to those released after an election) induced a significant short-term reduction in municipal corruption levels, that then later dissipated in the subsequent rounds of audits. An important distinction between our studies is that in our context the audits are conducted at random, and thus politicians are not able to anticipate them. Di Tella and Schargrodsky (2003) examine the effects of an anti-corruption crackdown and found that the prices paid for homogenous supplies by public hospitals in Buenos Aires fell by 15 percent after the government began to disseminate information on prices. Olken (2007) implemented a randomized experiment where prior to the start of a national wide infrastructure project, villages in Indonesia were randomly assigned into groups with different audit probabilities. The study found that 24 percent of reported funds were found to be 'missing", but when faced with a certain audit this difference was reduced by 8 percentage points. Zamboni and Litschig (2015) investigate the effects of a randomized experiment conducted by the Controladoria-Geral da União (CGU) designed to test whether increased audit risk reduces corruption and mismanagement. In this experiment, the CGU announced in May of 2009 to 120 municipalities that in one year time, 30 of them would be randomly selected for an audit. Based on this temporary increase in audit risk of about 20 percentage points, the authors found that the treatment reduced the proportion of local procurement processes involving waste or corruption by 
about 20 percent. Finally, Lichand et al. (2016) also examine the effects of Brazil's audit program with a focus on corruption in health. Using a difference-in-differences strategy, the study tests whether corruption is lower in municipalities that neighbor municipalities that were audited in the past. Consistent with our spillover effects on corruption across all sectors, they find that corruption in health reduced by 5.4 percent in places that neighbor an audited municipality.

We complement these studies in various ways. First, our findings suggest that audits can be an effective policy instrument for not only promoting electoral accountability, but also enhancing judicial punishment. Second, there are several motives for reducing corruption in response to an audit. In our study, we are able to decompose the effects of these various channels, and highlight the relative importance of non-electoral costs in disciplining the behavior of politicians. Third, our results demonstrate that even when audit probabilities are held constant, the mere act of being audited can impact an individual's subjective probability of being found to be corrupt. Finally, another advantage of our data is the ability to distinguish between acts of corruption versus acts of mismanagement. ${ }^{5}$ We do not find any evidence that the audits reduced irregularities associated with mismanagement.

Our study also contributes to a body of research documenting the importance of legal institutions for economic development, and in particular corruption (e.g. Glaeser and Shleifer (2002); La Porta et al. (2004)). For example, Glaeser and Goldin (2006) argue that reduction in corruption over time in the U.S. was due to a combination of increasing political competition, an active media uncovering corruption scandals, and an independent judiciary that successfully prosecuted corrupt officials. Also using variation across U.S. states, Alt and Lassen (2008) show that corruption is much lower among states in which state supreme court judges are elected rather than appointed. Finally, Litschig and Zamboni (2015) exploit variation in the presence of the judiciary across Brazil's municipalities to show that corruption is lower in municipalities with a state judiciary present. In contrast to these studies, however, we show using data on the arrests and convictions of politicians that audits can be a critical instrument in promoting judicial accountability. As far as we know, this is the first paper that examines how both political and judicial accountability can affect corruption.

Finally, our study also relates to a growing empirical literature that examines the relationship between electoral accountability and politician performance. There is a growing literature showing that when voters are informed, elections can discipline corrupt politicians (e.g. Ferraz and Finan (2008), Winters and Weitz-Shapiro (2013)). Similarly, a series of papers have exploited variation

\footnotetext{
${ }^{5}$ Recent studies have tried to distinguish between active and passive waste. For example, Bandiera et al. (2009) use data on public procurement from Italy to show that more than 80 percent of waste can be classified as passive.
} 
in term limits to show that incumbents respond to re-election incentives. For example, Besley and Case (1995) show that re-election incentives affect the fiscal policy of U.S. governors, while List and Sturm (2006) provide evidence that term limits even influence secondary policies, such as environmental policy. In relation to the Brazilian context, Ferraz and Finan (2011) find that mayors who are in their second term, and hence do not have opportunity for re-election, engage in much more corruption relative to mayors with re-election incentives. Similarly, de Janvry et al. (2012) find that Brazil's Bolsa Escola - a conditional cash transfer program that was targeted in a decentralized manner - performed much better in places where mayors had re-election incentives.

While these studies provide convincing evidence consistent with standard political agency models, they are unable to quantify the electoral selection effects that are also central to models of political accountability. Recently, some progress has been made in this direction by taking a more structural approach. Aruoba et al. (2015) estimate a model of political accountability to quantify the discipline and selection of U.S. gubernatorial elections. Using data from 1982-2012 of U.S. governors, they find that the possibility of re-election leads to a 13 percentage point increase in the fraction of governors who exert high effort in their first term in office, as measured by voters' job approval. Although set in a different context, they too find weaker selection effects: the fraction of good governors rises by 8 percentage points from the first to second term in office. Our paper complements this study by not only disentangling selection from incentive effects, but also allowing for the possibility a non-electoral disciplining effect.

The rest of the paper is organized as follows. Section 2 provides background on the Brazil's anticorruption program and presents the data used in the empirical analysis. Section 3 presents the theoretical framework. Section 4 discusses our research design and in Section 5 we present our reduced-form findings. In Section 6 we discuss the estimation of the model and present our counterfactual simulations. Section 7 concludes.

\section{Background and Data}

\subsection{Corruption in Brazil and the Randomized Anti-Corruption Program}

Brazil is one of the most decentralized countries in the world. Each year, municipalities receive millions of dollars from the federal government to provide basic public services such as primary education, health care, and sanitation. An elected mayor decides how to allocate these resources in 
conjunction with a locally-elected legislative body. With only minimal federal oversight accompanying these transfers, corruption at the local level has been a serious concern.

Corruption in Brazil occurs through a combination of fraud in the procurement of goods and services, diversion of funds, and over-invoicing of goods and services (Ferraz and Finan (2011)). Common irregularities include incomplete public works (paid for but unfinished) and the use of fake receipts and phantom firms (i.e., firms that only exist on paper). Places that receive more federal transfers, or where the local media and the judiciary are absent, tend to experience relatively more corruption(Brollo et al. (2013), Zamboni and Litschig (2015)).

In response to the wide spread corruption, and a lack in the capacity to systematically detect and punish malfeasance, the federal government implemented an institutional reform to increase the cost of engaging in corruption. In 2003, it created Brazil's Controladoria Geral da União (CGU) -Office of Comptroller-General- by unifying various pre-existing agencies within the government, and affording it the constitutional powers of a ministry. Shortly after its creation, the CGU launched an anti-corruption program targeted at municipal governments. The program, named Programa de Fiscalização por Sorteios Públicos (Monitoring Program with Public Lotteries), consists of random audits of municipalities for their use of federal government funds. It originally started with the audit of 26 randomly selected municipalities across different states, but then shortly moved towards auditing 60 municipalities every two to four months. The lotteries are publicly held in conjunction with the national lottery in Brasilia and all municipalities with a population of up to 500,000 inhabitants are eligible for selection. ${ }^{6}$ As of February 2015, there have been 2,241 audits across 40 lotteries in 1,949 municipalities, and over $\mathrm{R} \$ 22$ billion dollars worth of federal funds audited.

Once a municipality is chosen, the CGU gathers information on all federal funds transferred to the municipal government during the previous three to four years and issues a random selection of inspection orders. Each one of these orders stipulates an audit task for a specific government project (e.g. school construction, purchase of medicine, etc.) within a specific sector. ${ }^{7}$ Once these inspection orders are determined, 10 to 15 auditors are sent to the municipality for one to two weeks to examine accounts and documents, to inspect for the existence and quality of public work construction, and the delivery of public services. These auditors are hired based on a competitive public examination and earn highly competitive salaries, thus their incentives for corruption are lower than those of other bureaucrats in the federal level administration. Moreover, the inspections

\footnotetext{
${ }^{6}$ This eligibility criteria has changed slightly over time.

${ }^{7}$ Auditors do not have discretion in auditing other projects. In case they find clear evidence of corruption in their field work, they need to notify the central unit of the CGU who will then decide whether to issue a new inspection order.
} 
are done by a team which reduces the opportunity for corruption among individual auditors. ${ }^{8}$ After the inspections are completed, a detailed report describing all the irregularities found is submitted to the central CGU office in Brasilia. The central unit unifies the information and publishes a report on the internet. These reports are also sent to the Tribunal de Contas da União (TCU), to public prosecutors, the Federal Police, and to the municipal legislative branch.

Over time the program has changed in order to improve the auditing capabilities of the CGU. Because it is easier to audit several government programs and contracts in smaller municipalities, the CGU decided in August 2005 to target the audits in larger municipalities - those above 20,000 inhabitants - to a limited number of sectors, which are also selected at random across lotteries. In the $17^{\text {th }}$ lottery that took place in August 2005, for example, the sectors chosen were social assistance, crime prevention, and industrial policies. Municipalities smaller than 20,000 inhabitants, on the other hand, are subject to audits in all sectors.

Although these changes affect the areas in which municipalities can be audited, they do not affect a municipality's audit probability. Lotteries are done by state so the probability of being audited is constant for municipalities within the same state. The number of municipalities that get audited within a state has varied slightly over time. For smaller states such as Alagoas only 1 or 2 municipalities are typically drawn in a single lottery, whereas for a large state like Minas Gerais, with over 853 municipalities, as many as 8 municipalities have been drawn in a single lottery. Overall, as we see from Table A.1, the implied audit probabilities are quite small, with the average being only 1.3 percent (s.d.=0.005) in a given lottery. Once a municipality is audited, it can only be audited again after 3 lotteries have elapsed.

By various accounts, the program has served as an important weapon in Brazil's fight against political corruption. The information obtained from the audits has been widely used in political campaigns and in voters' selection of municipal politicians (Ferraz and Finan (2008)). The federal police and federal prosecutors have also exploited the audits to better target their investigations, and to help build their cases against corrupt politicians and public servants. Consequently, since 2004 Brazil has witnessed a steady increase the number of legal actions involving political corruption, evidence of which can be seen in Figure 1.

Panel A of Figure 1 plots the number of police crackdowns, called Operações Especiais (Special Operations), aimed at uncovering municipal corruption. These crackdowns, which have increased over time and to date total 199 cases throughout Brazil, are the result of a direct collaboration between the federal police and the CGU. The number of civil court cases of individuals charged

\footnotetext{
${ }^{8}$ In Ferraz and Finan (2008), we find no evidence that auditors manipulate the audit reports.
} 
with misconduct in public office has also increased since 2004. In Panel B, we plot the number of mayors convicted of misconduct in public office who are banned for running for any public office for at least five years. As the figure depicts, while less than 50 mayors were convicted of irregularities in 2004, more than 400 were convicted in 2009. Although the CGU is not solely responsible for the increase in anti-corruption crackdowns and convictions, it has undoubtedly increased the costs of corrupt practices in Brazil, and as we will document below, its random audit program has play a significant role in this increase.

\subsection{Data}

We build measures of mismanagement and corruption from a database obtained from the CGU. The dataset includes the coding of irregularities found by the auditors for each inspection order. While all audit reports are posted online, starting with the $20^{\text {th }}$ lottery in March 2006, the CGU began to code the information that was used as an input for the reports for internal use. For each inspection order, the dataset contains information on the sector and government program, the amount transferred to the municipality, and a list of findings. For each finding, the auditors describe the irregularity found and assign a code that classify irregularities into three categories of wrongdoing, ranging from simple procedural issues, such as missing documents on a procurement process to moderate and severe irregularities, such as large withdrawals from checking accounts with no receipts on how the resources were spent.

To illustrate the classification scheme used by the CGU, take for example the municipality of Chaval in Ceará, which was audited in the $20^{\text {th }}$ lottery. The auditors went to the municipality with 25 inspection orders, one of which involved the financing of school buses for students attending primary schooling. Here, they discovered two irregularities. For the first irregularity, which was classified as moderate, a representative of the mayor used a check to withdrawn $\mathrm{R} \$ 1,200$ without proving how the money was spent. The second irregularity, which was classified as severe, took place during the procurement of transportation services. The contract was awarded to a firm that did not match the original proposal, and the value of the contract was for a different amount than what was offered.

Based on this information, we construct measures of corruption and mismanagement at the municipalitylottery level. Our measure of corruption is the number of irregularities classified as either moderate or severe. Our measure of mismanagement is the number of irregularities associated with administrative and procedural issues. In Figure 2, we plot the distributions of irregularities associated 
with corruption and mismanagement per service order. The audits discover on average 2.5 acts of corruption and 0.88 acts of mismanagement per service order, suggesting that 73.6 percent of the irregularities found during an average audit involves some acts of corruption. To put these figures in perspective, Bandiera et al. (2009) estimate only 20 percent of waste found in Italy's public procurement process was due to corruption. Similarly, Olken (2007) argues that the main reason why audited villages in Indonesia did not significantly reduce their corruption is because the audits mostly reveal acts of mismanagement as opposed to acts of malfeasance. Similar to Bandiera et al. (2009) we do not find any evidence that active and passive are positively correlated (correlation coefficient $=0.02$ ). In Figure 3 , we plot the average number of irregularities associated with corruption and mismanagement by lottery. While our measure of corruption has been increasing steadily over time, the acts of mismanagement has varied more, particularly in recent audits. Given the changes to the auditing protocol over time, one should be cautious to interpret this temporal variation. In the regression results, we control for time trends in audit practices and exploit only within-audit variation.

Four other data sources are used in this paper. The political outcome variables such as reelection, vote shares, and mayor characteristics come from the Tribunal Superior Eleitoral (TSE), which provides results for the 2004-2012 municipal elections. These data contain vote totals for each candidate by municipality, along with various individual characteristics, such as the candidate's gender, education, occupation, and party affiliation. With this information, we matched individuals across elections to construct measures of reelection and whether mayors are serving on a first versus second-term.

We constructed the data on the joint CGU-Federal Police crackdowns using the information available on the CGU homepage. ${ }^{9}$ For each year starting in 2003 the CGU lists the name of the Special Operations and a description of the target. For each crackdown, we searched for the name of each operation together with the names of the targeted municipalities and keywords such as "mayor" or "corruption". We created a dataset comprised of the name of each municipality targeted by the special operation, a description of the findings, and whether the mayor or public servants of the targeted municipalities were involved in and/or arrested during the crackdown. Using this information we created an indicator that equals to one if a municipality was subject to a crackdown in a given year and whether the mayor was involved in the irregularities and/or arrested.

Data on the convictions of mayors for misconduct in public office was obtained from the Cadastro Nacional de Condenações Cíveis por ato de Improbidade Administrativa e Inelegibilidade. This

\footnotetext{
${ }^{9}$ See http://www.cgu.gov.br/assuntos/auditoria-e-fiscalizacao/acoes-investigativas/operacoes-especiais
} 
database, administered by the National Council for Justice (CNJ), includes the names of all individuals charged of misconduct in public office. We downloaded the data in 2013 so the dataset includes all agents convicted up to that point. For each individual we observe the type of irregularity (e.g. violation of administrative principles or diversion of resources), the court where the conviction took place, and the date. These data were then matched to the electoral data based on where the individual was a mayor and the period he/she served in office. Individuals on this list are banned from running for any public office for at least five years.

Data on municipal characteristics come from the Brazilian Institute of Geography and Statistics (Instituto Brasileiro de Geografia e Estatística (IBGE)). The 2000 population census provides several socioeconomic and demographic characteristics used as controls in our regressions. Some of these key variables include income per capita, income inequality, population density, share of the population that lives in urban areas, and share of the population that is literate.

To control for different institutional features of the municipalities, we also use information from 1999 municipality survey, Perfil dos Municípios Brasileiros: Gestão Pública. This municipal survey characterizes not only various aspects of the public administration, such as budgetary and planning procedures, but also more structural features such as the percentage of roads that are paved, and whether the municipality has a judge. Moreover, the survey provides our key measures of media availability, namely the number of radio stations and the number of daily newspapers. The richness of this dataset allows us to comprehensively check the validity of our research design, and control for any potential confounding factors in the regressions that do not entirely rely on the randomization.

Table 1 presents summary statistics for the municipalities in our sample, by whether they were audited previously or not. For each characteristic, we also present the difference between these characteristics. As expected from the random assignment, there is little difference in characteristics between places that were audited for a first time compared to those that have previously been audited. Importantly, included among these characteristics is the number of service orders. The fact that the number of service orders is balanced between treatment and control verifies the fact that the CGU does not adjust the number of service orders based on a previous audit. ${ }^{10}$ Out of 15 characteristics, only one is statistically significant at the 10 percent level. We also fail to reject the hypothesis that all the variables are jointly significant $(\mathrm{F}$-test $=1.17 ; p$-value $=0.30)$. Overall the results from Table 1 suggest that the lottery used by the CGU was effective.

\footnotetext{
${ }^{10}$ This is expected given the way inspection orders are issued. As we mentioned, within sectors inspection orders are issued based on a random selection of government projects from the last 3 to 4 years.
} 


\section{Model}

To disentangle the channels through which audits may reduce corruption, we consider the following two-period model of career concerns. There are two players, a mayor and a representative voter. In the first period, the incumbent chooses the effort he will make to extract rents taking reelection incentives into consideration. Politicians differ along a single unobserved ability dimension. The ability of the incumbent is randomly drawn after he chooses his action. ${ }^{11}$ First period rents are a function of the incumbent's effort and ability. The voter observes first period rents with a fixed probability and chooses whether to reelect the incumbent or select a challenger who is randomly drawn from the pool of potential politicians. In the second period, the reelected incumbent or the newly selected politician chooses his action. If the mayor is newly elected, his ability is realized. Finally, second period rents are realized and the game ends.

\subsection{The Mayor}

Mayors differ along a single dimension, which we call ability. Mayors with high ability extract more rents than those with low ability. The ability of a mayor $i$ is denoted by $\varepsilon_{i}$ and is constant over his tenure in office. We assume that ability is drawn from a normal distribution with mean 0 , such that $\varepsilon_{i} \sim N\left(0, \sigma^{2}\right)$.

Mayors face a two-term limit. The mayor seeks to maximize the discounted sum of rents $r$ and ego utility $E$, net of the costs of rent extraction $c$ over his tenure. Rents in term $t$ for mayor $i$ are given by the sum of the mayor's effort $e_{t}$ and the mayor's ability $\varepsilon_{i}$. In period $t$, the mayor's utility is

$$
u_{i t}\left(e_{t}\right)=e_{t}+\varepsilon_{i}+E-c\left(e_{t}\right)
$$

For ease of exposition, we assume that the cost of rent extraction is quadratic in rents. Thus we assume $c\left(e_{t}\right)=\frac{e_{t}^{2}}{2 \gamma}$, where $\gamma$ denotes the efficiency of the rent extraction technology, or equivalently, the reciprocal of the cost parameter. In practice, these costs include the reputation and legal costs a mayor may incur if his rents are exposed.

Now consider a first term mayor. The mayor discounts period 2 utility by $\beta$. Depending on the mayor's first period action, the mayor may be reelected $(R=1)$ or not reelected $(R=0)$. If the

\footnotetext{
${ }^{11}$ To keep the model tractable, we do not consider the case where the mayor observes his type before choosing his action. In an earlier draft of this paper, we solved and estimated such a model with adverse selection and found qualitatively the same results at the cost of greater complexity.
} 
mayor is not reelected, we normalize his utility to 0 in period 2. The mayor's maximization problem in the first period is

$$
\max _{e_{1}} u_{1}\left(e_{1}\right)+\beta E\left[u_{2} \mid e_{1}\right]
$$

\subsection{The Voter}

We assume that there is a representative voter and adapt the standard probabilistic voting model. Before the election, the mayor's popularity shock $\delta$ is drawn from a uniform distribution with mean $\mu$ and density $\eta$. Moreover, the voter observes period 1 rents with probability $\chi$. Otherwise, the voter does not observe rents and only bases his vote on the popularity shock. If the voter observes $r_{1}$, he updates his belief on the mayor's type to $\tilde{\varepsilon}_{i}=r_{1}-e_{1}^{*}$, where $e_{1}^{*}$ denotes the equilibrium first period effort. Assuming a rational expectation equilibrium, the expression simplifies to $\tilde{\varepsilon}_{i}=\varepsilon_{i}$.

After observing the popularity shock and (possibly) period 1 rents, the voter chooses whether to reelect the incumbent or select a challenger who is drawn at random from the pool of potential politicians. For tractability, we assume that the game ends at the end of the second period. ${ }^{12}$ The voter's value function is given by $V=\delta-e_{2}^{*}-\tilde{\varepsilon}_{i}$ if he reelects an incumbent $i$ or $V=-e_{2}^{*}$ if he selects a new candidate.

\subsection{Equilibrium}

To recap, the timing of the game is as follows. The first term incumbent picks an action $e_{1}$. The incumbent's ability $\varepsilon_{i}$ is realized and actual first term rents are $r_{i 1}=e_{1}+\varepsilon_{i}$. Then, the voter observes $r_{i 1}$ with probability $\chi$ and the incumbent's shock $\delta$ is realized. Elections are held. In the second period, the incumbent selects an action $e_{2}$. Second term rents are $r_{i 2}=e_{2}+\varepsilon_{i}$, where $\varepsilon_{i}$ is newly drawn if the challenger was elected.

We solve for the Perfect Bayesian Equilibrium. Consider a second term mayor. Maximizing (1) in period 2 yields the first order condition

$$
e_{2}^{*}=\gamma
$$

Thus period 2 rents are given by $r_{i 2}=\gamma+\varepsilon_{i}$.

Consider next the voter's problem. The voter seeks to maximize the sum of his period 2 utility

\footnotetext{
${ }^{12}$ The solution to the model is almost identical for an infinitely-lived voter, with the only change lying in a difference in the voter's value function. We prefer the two-period model for analytical tractability.
} 
and the utility he derives from the incumbent's popularity shock. Conditional on his belief on the mayor's type, the probability of the mayor's reelection is

$$
\begin{aligned}
P\left(R=1 \mid \tilde{\varepsilon}_{i}\right) & =\chi P\left(\delta \geq \tilde{\varepsilon}_{i}\right)+(1-\chi) P(\delta \geq 0) \\
& =\frac{1}{2}+\eta \mu-\chi \eta \tilde{\varepsilon}_{i}
\end{aligned}
$$

Therefore, the mayor's expected period 2 utility conditional on his period 1 action is

$$
\begin{aligned}
E\left[u_{2} \mid e_{1}\right] & =\int E\left[u_{2} \mid e_{1}, \varepsilon_{i}, R=1\right] P\left(R=1 \mid e_{1}, \varepsilon_{i}\right) f\left(\varepsilon_{i}\right) \mathrm{d} \varepsilon_{i} \\
& =\int\left(\frac{\gamma}{2}+\varepsilon_{i}+E\right)\left[\frac{1}{2}+\eta \mu-\chi \eta\left(e_{1}-e_{1}^{*}+\varepsilon_{i}\right)\right] f\left(\varepsilon_{i}\right) \mathrm{d} \varepsilon_{i} \\
& =\left(\frac{\gamma}{2}+E\right)\left[\frac{1}{2}+\eta \mu-\chi \eta\left(e_{1}-e_{1}^{*}\right)\right]-\chi \eta \sigma^{2}
\end{aligned}
$$

Thus the solution to the first-term mayor's maximization problem (2) is given by the first-order condition

$$
e_{1}^{*}=\gamma\left[1-\beta \chi \eta\left(\frac{\gamma}{2}+E\right)\right]
$$

\subsection{The Effects of Audits}

In this section, we consider the channels through which audits may affect corruption, which we measure by rents in the model. The expected rents of a first-term mayor in the first period are

$$
E\left[r_{1}\right]=\underbrace{\gamma}_{\text {non-electoral costs }}-\underbrace{\gamma \beta \chi \eta\left(\frac{\gamma}{2}+E\right)}_{\text {electoral discipline }}
$$

We refer to the first term in (6) as the non-electoral costs channel, which is defined as the amount of rents which would be extracted in a benchmark model without reelection incentives. In this benchmark, the only constraint to rent extraction are the non-electoral costs captured by the parameter $\gamma$. We refer to the second term in the right-hand-side of (6) as the electoral discipline channel. It denotes the decrease in first-term rents due to the reelection incentive.

To determine the expected rents of a second-term mayor, we first derive the expected type of the 
mayors who are reelected. Using Bayes' rule, we find that

$$
E\left[\varepsilon_{i} \mid R=1\right]=\frac{-\chi \eta \sigma^{2}}{1 / 2+\eta \mu}
$$

Thus, the expected rents of a second-term mayor in the second period are:

$$
E\left[r_{2}\right]=\underbrace{\gamma}_{\text {non-electoral costs }}-\underbrace{\frac{\chi \eta \sigma^{2}}{1 / 2+\eta \mu}}_{\text {political selection }}
$$

We label the first term in (7) the non-electoral costs channel. This term represents the amount of rents which would be extracted if second-term mayors were randomly selected from the pool of candidates. This amount is restricted only by the cost of rent extraction. The second term in (7) is the political selection channel. It measures the decrease in second-term rents which is due to elections selecting mayors who extract fewer rents.

Audits may affect several structural parameters in the model. We consider the following three possibilities, highlighting the channels through which rents would be decreased in each case.

A change in the probability of detection by voters. The first possibility we consider is that audits affect the intensity of monitoring by voters. If voters monitor politicians more closely after the experience of an audit, then we would expect that $\chi$, the probability that rents are detected by voters, increases in treated municipalities. An increase in $\chi$ reduces expected rents in both terms. The decrease in term 1 is due to the electoral discipline channel, as the audit causes the mayor's probability of reelection to become more sensitive to changes in rents. The decrease in term 2 is due to the political selection channel, as voters become more likely to reelect mayors who extract less rents.

A change in the costs of rent extraction. Recall that $\gamma$ denotes the efficiency of the technology of rent extraction. Thus, if the experience of an audit increases the expected cost of rent extraction, then we would expect $\gamma$ to decrease. The increase in the expected cost need not be objective: it could be due to an increase in the mayor's perception of the probability of future audits or due to an increase in the perception of the cost of rents conditional on being audited (for example, a mayor might update this belief after observing the arrest or conviction of a previous mayor). A decrease in $\gamma$ decreases first-term rents through two channels: it has a direct effect by increasing the non-electoral costs of rent extraction and an indirect effect by reducing the mayor's reelection incentive. Furthermore, a decrease in $\gamma$ reduces second term rents through the non-electoral cost 
channel.

A change in the distribution of types of potential mayors. Audits could also lead to a change in the pool of candidates who run for mayor. A change in the mean ability of potential mayors has the same effect on rents as a change in $\gamma$. The economic interpretation however is different: an increase in the mean ability of mayors would imply that better candidate types enter politics following an audit, a political entry effect, whereas a decrease in $\gamma$ would imply no effect on candidate entry.

\section{Research Design}

We are interested in testing whether audits reduce future corruption. To test this hypothesis, we need to overcome the fact that we only observe corruption once a municipality has been audited. We do so by exploiting municipalities that have been audited multiple times. As we see in Figure 4, out of the 1,949 municipalities that have been audited, 25 percent of them have been audited multiple times: 253 audited twice, 18 three times, and 1 municipality 4 times. For a given round of audits, we can compare the corruption levels of municipalities that had been audited prior to this audit to those that had not (and are thus being audited for the first time).

Figure 5 shows the main variation we will exploit. The first time a municipality was audited for a second time occurred in the $11^{\text {th }}$ lottery. As expected, the number of municipalities that have been audited more than once increases over time. For instance, in the $30^{\text {th }}$ lottery out of the $60 \mathrm{mu}$ nicipalities audited, 19 had been audited in the past. Note that because the lotteries are conducted at random, for a given lottery at time $t$ the probability that a municipality has been audited in the past is the same for all municipalities within a particular state. Given this structure of the data, we estimate the following model for municipality $m$ in state $s$, audited at date $t$.

$$
\text { Corruption }_{m s t}=\alpha+\beta \text { Past Audit } \text { Ast }+X_{m s}^{\prime} \gamma+f(\text { nos })_{m s t}+v_{s}+\delta_{t}+\varepsilon_{m s t}
$$

where Corruption $_{m s t}$ is the amount of corruption detected in municipality $m$ during audit $t$, and

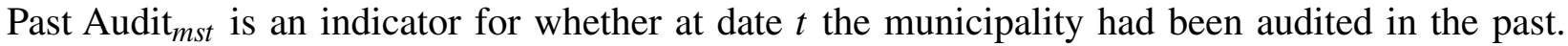
The vector $X_{m s}^{\prime}$ consists of a set of municipal characteristics (e.g. population, income per capita, income inequality, etc.) measured in 2000. These controls allow us to account for any socioeconomic differences across municipalities prior to the start of the program. The variable nos ${ }_{m s t}$ denotes the number of service orders that auditors were sent to investigate. Since audits with more service orders tend to discover more irregularities, it is important to account for these differences 
in a flexible manner. In our preferred specification, the number service orders is controlled for completely non-parametrically. The error term, $\varepsilon_{m s t}$, captures unobserved (to the econometrician) determinants of corruption.

Importantly, our model also adjusts for two classes of fixed-effects. We include state intercepts, $v_{s}$, to capture the fact that the randomization is stratified by state. ${ }^{13} \mathrm{We}$ also include lottery fixed effects, $\delta_{t}$, which are important for two reasons. First, although municipalities are more likely to become treated over time, within a given lottery, the probability that a municipality had been audited in the past is the same for municipalities within the same state. Second, and more importantly, starting in the $20^{\text {th }}$ lottery, the CGU began to audit funds in selected areas and programs. It is thus difficult to compare corruption levels over time, and hence we restrict our analysis to variation within audits. Because municipalities are audited at random, we can interpret the coefficient $\beta$ as the causal effects of the audits on corruption.

In addition to estimating the effects on corruption, we also test whether mayors are more likely to be investigated by the federal police or convicted in places that have been audited. In this case, we estimate the following specification:

$$
\operatorname{Legal}_{m t}=\alpha+\beta \text { Audited }_{m t}+v_{m}+\delta_{t}+\varepsilon_{m t}
$$

where Legal $_{m t}$ is an indicator for whether a legal action (e.g. crackdown involving political corruption or the mayor was convicted for corruption) occurred in municipality $m$ in year $t$. Our treatment variable, Audited $_{m t}$, which is equal to one after an audit, estimates the causal effect of being audited on the likelihood of incurring a legal action. The regression adjusts for municipal and year fixed effects, and the error term is clustered at the level of municipality.

\footnotetext{
${ }^{13}$ Given the population density of North Brazil, when CGU draws municipalities for audit, this region, which includes the states of Acre, Amapá, Amazonas, Pará, Rondônia, Roraima and Tocantins, is treated as a single state.
} 


\section{Results}

\subsection{Reduced-form Estimates}

\section{Effects of the Audits on Corruption and Mismanagement}

Table 2 presents OLS regression results from estimating several variants to Equation 8. The specification in the first column estimates the effects of having been audited on the total number of irregularities discovered in the audit, controlling for state and lottery intercepts, as well as the number of service orders. Column 2 extends this specification to include various socio-economic characteristics of the municipality. Our preferred specification is presented in Column 3, which modifies the specification in Column 2 to control for the number of service orders in a nonparametric manner.

The results in columns 1-3 suggest that municipalities that had been audited in the past commit significantly fewer irregularities than those that had not been previously audited. Once we control for municipal characteristics and service-order fixed-effects, we estimate a reduction of 5.8 percent. We also find that the number of irregularities correlates with several municipality characteristics as we have come to expect from the cross-country literature. For example, we see strong negative associations with income per capita and literacy rates, as well as positive correlations with income inequality and population.

As we have discussed above, there is an important distinction to be made between corruption and mismanagement, which we distinguish between in columns 4-9. In columns 4-6, we replicate the previous specifications using as a dependent variable the log of total acts of mismanagement. In columns 7-9, we use the log of total acts of corruption as the dependent variable.

We do not find any evidence that audits affect mismanagement. Under our preferred specification, the point estimate is small and statistically indistinguishable from zero (coefficient $=-0.023$, robust standard error=0.041). In contrast, we find that having been audited in the past leads to a significant reduction in corruption. Municipalities that had experienced a previous audit committed 7.9 percent less acts of corruption compared to those that had not. In order to interpret this magnitude, consider that the average municipality in our sample receives $\mathrm{R} \$ 15,000,000$ in federal transfers per year. Based on our estimates of a random sample of audit reports, 30 percent of the funds audited were found to be diverted, implying that audits reduced corruption by $\mathrm{R} \$ 355,000$ per year per municipality. The municipal characteristics are also quite predictive of corruption levels: for example, a 10 percent increase in per capita income is associated with a 1.8 percent decline in corruption. 
In Table A.2, we test whether the effects of the audits vary according local characteristics. Overall, we find little evidence of heterogenous effects. There is modest evidence that the effects of the audits may have been more pronounced in places with a larger share of college graduates or in more urban places, but the effects are not robust once we account for the interaction terms jointly (see column 10). The lack of heterogeneous effects is not too surprising given our specification. Ideally, we would also like to condition on a municipality's prior level of corruption, but unfortunately and by construction, we do not observe prior levels of corruption in places that had not been audited in the past.

\section{Spillover Effects}

The estimates presented in Table 2 are likely to represent a lower bound for the reduction of corruption caused by the audits. If control municipalities are learning about the audits either through the media or from an audited neighbor, then they too might be refraining from corruption. We explore this possibility in Table 3. In column 1, we re-estimate Equation 8, adding the number of neighboring municipalities that have experienced an audit as an additional independent variable. To account for the fact that municipalities have different numbers of neighbors, we also control non-parametrically for the number of neighbors. Moreover, because a municipality might not learn about another municipality's audit, even if neighbors, in columns 2 and 3 we introduce an interaction term for whether local media is present, which increases the likelihood that one learns about neighboring audits.

In column 1, we estimate that for each additional treated neighbor, a municipality reduces its corruption by 2.0 percent, but this effect is not statistically significant. The coefficient on our main treatment variable is nearly identical to those presented in Table 2, suggesting that even when controlling for spillover effects from neighboring municipalities, fewer acts of corruption are uncovered in municipalities that have been audited in the past.

In columns 2-3, we test whether the spillover effects are more pronounced when the media has a presence in the municipality. For both AM radio (column 2) and television (column 3), we find evidence of significant spillover effects. We estimate that an additional audited neighbor decreases corruption by 7.5 percent when AM radio is present, and by 10.4 percent for local television. We find no evidence of spillover effects in municipalities without the presence of the media. In column 4, we re-estimate the equation, allowing for the spillover effects to vary by share of the population with a college degree, income per capita, and the share of urban population. Even after allowing for differential effects along these other characteristics, the heterogeneous effects by AM radio and 
local television remain robust. ${ }^{14}$

Overall, these findings suggest that we are underestimating the audit program's true impact on corruption. Municipalities that are presumably learning about the potential effects of the audits are engaging in less corruption, even if they had not experienced an audit themselves.

\section{Effects of the Audits on Legal Actions}

After an audit, the municipality (and its neighbors) has learned about not only the audit process and the extent to which corruption can be detected, but also its legal consequences. As we depicted in Figure 1, both police crackdowns and convictions have increased substantially over time, presumably in response to the program. In Table 4, we investigate the effects of being audited on the likelihood that the municipality faces a subsequent legal action. In columns 1-6, we estimate variants of Equation 9 with three sets of dependent variables: a police crackdown involving political corruption occurred (columns 1 and 2), mayor was convicted for corruption (columns 3 and 4), and either a crackdown occurred or a mayor was convicted (columns 5 and 6). Because we are not limited to municipalities that have been audited at some point in time, we estimate these specifications for the entire sample of municipalities eligible for an audit.

Compared to non-audited municipalities, municipalities that have experienced an audit are much more likely to face a subsequent legal action, as measured by either a police crackdown or a mayor conviction. Municipalities that have been audited in the past are 0.5 percentage points more likely to face a legal action than those that have not been audited. Given that only 2.6 percent of control municipalities have experienced a legal action, the treatment effect represents an increase of 20 percent. In columns 2, 4 and 6, we find that the effects of the treatment are largely concentrated in places with a judiciary district. Among these municipalities, the treatment increased the likelihood of a legal action by 35.4 percent, relative to control municipalities with a judiciary district.

While informative, the specifications presented in columns 1-6 would ideally also condition on the level of corruption in the municipality. Because we do not observe this information in places that have not been audited, in columns 7-9 we estimate the simple correlations between legal actions and acts of mismanagement and corruption. Not surprising, we find that corruption is strongly associated with the likelihood of a legal action. For example, a 1 percent increase in number of corruption acts is associated with a 8.8 percent increase in the likelihood of a legal action. In con-

\footnotetext{
${ }^{14} \mathrm{We}$ also replicate these findings when using a dummy for the presence of at least one neighboring audit, instead of the number of neighboring audits.
} 
trast, we do not find any evidence that acts of mismanagement are associated with any legal costs. Overall these findings suggest that the non-electoral costs of engaging corruption are substantial.

\subsection{Mechanisms}

Thus far, the evidence suggests that having been audited in the past substantially reduces future corruption and increases the likelihood of a legal action in the municipality. In Section 3, we discussed four reasons why the audits may reduce corruption. The first is a political selection effect among mayors that are reelected. If audits allow voters to punish corrupt mayors and reward good ones, then we would expect better politicians in places where the incumbent was audited prior to the election and still re-elected. The second channel is an electoral disciplining effect. If audits increase the objective (or perceived) future probability of being exposed to voters, then mayors who have re-election concerns will refrain from corruption. The third channel is what we have termed a non-electoral disciplining effect. Mayors may refrain from corruption even in the absence of reelection incentives, lest they incur reputation or legal costs. If the experience of a previous audit in the same municipality increases the mayor's subjective belief on the probability or the magnitude of these costs, then such mayors will refrain from corruption. The fourth channel is a political entry effect, which would occur if audits induce a change in the distribution of mayor types who choose to enter into the candidate pool.

In this section, we present reduced-form tests of these various mechanisms, and isolate their effects under the assumption that they are constant and additive. In Section 6, we relax these restrictive assumptions and instead disentangle the channels by structurally estimating the model.

Electoral and Non-Electoral Disciplining Effects. To isolate the effects from electoral and nonelectoral discipline, we consider the set of municipalities in which a mayor experiences an audit early in his term (often over funds that he did not administer), and is then effectively audited again in the same term. ${ }^{15}$ In these cases, no election has occurred, which rules out the possibility of any audit-induced political selection or entry effect. Any difference in corruption levels between these municipalities and those that have not been audited (control group) can only be due to an electoral or non-electoral disciplining effect. We can then further distinguish between these two effects by estimating whether the effects vary by whether the mayor was in his first or second term. Because

\footnotetext{
${ }^{15}$ Note that the audit may have even occurred in the subsequent term, but the funds audited referred to those administered under the previous term.
} 
second-term mayors are term-limited, they should only respond to non-electoral costs, whereas first-term mayors will respond to both types of costs. ${ }^{16}$

We perform these comparisons in columns 1 and 2 of Table 5. In column 1, we compare to nonaudited places, municipalities in which the mayor experienced multiple audits within the same term. Based on this comparison, we find that the audits led to 12.7 percent reduction in corruption, which can be attributed to either an electoral disciplining effect, a non-electoral disciplining effect, or both. In column 2, however, we do not find a differential effect based on whether or not the mayor is in his second term, although the standard errors are admittedly large. But overall, these results provide suggestive evidence that for this subsample of mayors the reduction is coming primarily from a non-electoral disciplining effect.

Political Selection. The effect of political selection on corruption stems from voters reelecting at greater rates the mayors who are less corrupt. Thus, to test for the existence of the political selection channel, we compare mayors that were audited and re-elected to mayors who were not audited but were also re-elected. If, as documented in Ferraz and Finan (2008), the audits enable voters to punish corrupt politicians while rewarding non-corrupt ones, then places that were audited prior to the election and where the mayor was subsequently reelected should be, on average, positively selected, compared to those places that were not audited and the mayor was still reelected.

We present this comparison in column 3. Among municipalities where the mayor was re-elected, corruption levels were 14.9 percent lower in audited municipalities compared to non-audited municipalities. Note however, that this difference in corruption levels reflects both the change in the composition of mayor types (political selection), as well as a non-electoral disciplining effect. Thus given our previous estimate of the non-electoral disciplining effect (in column 1), and under the assumption of constant and additive treatment effects, these results suggest that political selection is actually playing a relatively minor role (i.e. a 2.2 percentage point difference) in how these audits

\footnotetext{
${ }^{16}$ An alternative approach would be to explicitly test whether voters punished corrupt politicians during the 2008 election. As documented in Ferraz and Finan (2008) for the 2004 elections, one could exploit the random timing of the audits to compare places that were audited prior to elections to those audited afterwards, conditional on the level of corruption discovered in the audit. Unfortunately, there are three drawbacks to replicating this approach for the 2008 elections. First, after the 2008 elections, audits became much less frequent, which in effect reduces the size of the control group. Second, as we mentioned in Section 2, after the $20^{\text {th }}$ lottery, the CGU changed how it conducted the audits. As a result, it is difficult to condition on corruption over time because the outcomes in one round of audits are not necessarily comparable to the outcomes in subsequent rounds of audits. Third, after the $16^{\text {th }}$ lottery, the CGU also changed the manner in which it disseminated its findings. It now posts the entire reports instead of summaries, which served as press releases. Those press releases were much more accessible to voters and media outlets. Nevertheless, when we use this approach to test whether voters punish corrupt politicians during the 2008 elections, we do not find any statistical evidence of an electoral disciplining effect.
} 
are reducing corruption.

Political Entry. A fourth channel through which audits may reduce corruption is political entry. This would be the case if the audits shifted the political equilibrium, whereby better candidates entered into politics. We test for this mechanism by comparing corruption levels in places that were audited at $t-1$ to those that were not, conditional on having a new mayor in time $t$ due to an open seat election. Conditional on having a new mayor at time $t$, there are three effects that could be driving this difference: electoral and non-electoral disciplining effects, and a political entry effect. With estimates of the first two effects, we can isolate the effects of audits through political entry.

In column 4, we find that compared to non-audited municipalities, corruption is 12.2 percent lower in places that were audited in the prior administration. Based on our estimates for the non-electoral disciplining effect, these results suggest that the political entry effect is zero and provide additional support for the importance of non-electoral costs.

As a further test for political entry, we examine whether the audits impacted the types of candidates that ran for office during open-seat elections. By focusing on open-seat elections, we obviate the direct effects of the audits on any potential candidate, given that the audits had taken place on a term-limited mayor. As such, any effects of the audits would have to come from changes to the political environment more generally. In Table 6, we examine whether the audits impacted the competitiveness of the elections, as well as the characteristics of the candidate pool and elected mayor. Consistent with a negligible entry effect, we find no evidence that the audits affected any of these election characteristics.

In sum, the results from Table 5 suggest that the audits' impact on corruption came largely from mayors updating their beliefs about the expected cost of rent extraction, which as we discussed need not be objective: it could be due to an increase in the mayor's perception of the probability of future audits or due to an increase in the perception of the cost of rents conditional on being audited.

\subsection{Alternative Mechanisms}

Displacement An alternative interpretation of our reduced-form findings is that politicians from previously audited municipalities are learning how to better hide corruption. In this case, corruption has not necessarily been reduced, but perhaps displaced. There are five reasons, however, why 
displacement is an unlikely interpretation. First, it is unlikely that displacement would have generated the spillover effects we documented in Table 3. Second, the set of programs and sectors that are subject to an audit vary over time, making it difficult for mayors to predict which specific areas and programs will be audited in the future. Third, based on the audit reports, we can classify how the corruption occurred. If places that have been audited in the past learned how to displace corruption, then we might expect an audit to affect the type of corruption committed in subsequent audits.

We explore this possibility in Table 7. Here, we estimate the effects of having been audited in the past on the share of corrupt acts associated with embezzlement, procurement contracts, and overinvoicing; three of the most common forms of corruption. ${ }^{17}$ In column $1-3$, we estimate the effects for the entire sample, and find no evidence that in places that had been audited in the past, mayors are more likely to shift away from or into these types of corruption. In columns 4-6, we restrict the sample to consider only those cases in which the mayor experienced multiple audits, which presumably is where the learning effects would be easiest to detect. But again, we find no evidence that the audits affected the nature of corruption in these places.

To further test the displacement hypothesis, we explore whether, across municipalities that are audited multiple times, less corruption is uncovered when the same sectors are audited. We estimate in column 7 the association between the amount of corruption detected during a second audit and the share of sectors investigated in both this and the municipality's previous audit. If mayors in treated municipalities are learning to better hide corruption, then presumably less corruption should be uncovered in places where the audits investigated funds in the same sectors. But as the result in column 7 indicates, the correlation, instead of negative, is positive and not statistically significant. As a final test of displacement, we examine whether the audits affect how municipalities spend their budgets. If local governments are displacing corruption by shifting their expenditures to sectors where corruption is harder to detect, then expenditure shares should be different in municipalities that have been audited in the past. For each audit, we compute the share of public expenditures spent in each sector during the given year using data from the Instituto de Pesquisa Econômomica Aplicada (IPEA). As Table 8 documents, we find no evidence that the treatment affected the manner in which municipalities allocated their budgets. In light of our previous discussion that mayors cannot anticipate which sectors and projects will be audited in the future, this result is not surprising.

\footnotetext{
${ }^{17}$ For each audit report, we create these shares by first counting keywords which are associated respectively with embezzlement, procurement contracts, and over-invoicing. We then divide the counts by the number of corrupt acts and finally we normalize the measures.
} 
Punishment from the Federal Government Another impact of the audits may have come from a reduction in the amount of block grants a municipality receives from the federal government. If this response in turn lowered the opportunity for mayors to engage in corruption, then this could explain the reduction in corruption we observe among previously audited places. As shown in Table 9, we do not find any evidence that having been audited in the past leads to a reduction in subsequent block grants. ${ }^{18}$

\section{Structural Estimation}

The key empirical challenge to distinguishing non-electoral discipline from electoral discipline and selection is that a decrease in first and second term rents could equally be caused, on the one hand, by non-electoral discipline, or on the other, by the combination of electoral discipline and selection (see equations (6) and (7)). The main advantage of the structural model over the reducedform model is that it allows us to disentangle non-electoral discipline from other channels without restricting the treatment sample to mayors who are audited twice in the same term. Instead, by exploiting data on the responsiveness of voters to corruption exposed before an election, we can structurally estimate the importance of the electoral and non-electoral channels in reducing rents.

\subsection{Data and Estimation}

We estimate the model for the sample of mayors audited in the year and a half preceding the 2012 mayoral elections. ${ }^{19}$ The sample consists of 319 audits, of which 87 are in the treatment group and 232 are in the control group. As in the reduced-form analysis, the treatment is defined as the previous experience of an audit in the same municipality. Each observation $i$ consists of the vector $\left(t_{i}, r_{i}, R_{i}, a_{i}\right)$, where $t_{i} \in\{1,2\}$ indicates the mayor's term, $r_{i}$ is the log of acts of corruption in the audit report, $R_{i}$ is a dummy for the mayor's reelection in 2012 and $a_{i}$ is a dummy for the treatment.

We estimate the model using maximum likelihood. Let $\theta:=\{\gamma, \chi, \mu, \sigma\}$ denotes the vector of parameters we seek to estimate. We allow the treatment to affect any of these parameters and hence

\footnotetext{
${ }^{18} \mathrm{We}$ also do not find an effect when we interact the treatment with amount of corruption discovered in the audits.

${ }^{19}$ We restrict the sample to these audits in order to exploit variation in reelection rates as a function of the corruption that is exposed through the audits. As a result, we need to select audits sufficiently late in a mayoral term so that they do not capture any corrupt acts of the previous term's mayor. We then focus on the 2009-2012 term because there are few treatment audits that occur shortly before the 2008 elections.
} 
estimate $\theta$ separately for the treated and control municipalities. We fix the remaining parameters $\beta, \eta$ and $E$. For a municipality $i$ where the mayor is in his first term, the likelihood is given by

$$
\begin{aligned}
L\left(r_{i}, R_{i} \mid t_{i}=1, \theta\right) & =f\left(r_{i} \mid t_{i}=1, \theta\right) P\left(R_{i} \mid r_{i}, \theta\right) \\
& =\phi\left(\frac{r_{i}-e_{1}^{*}}{\sigma}\right)\left(\frac{1}{2}+\eta \mu-\chi \eta\left(r_{i}-e_{1}^{*}\right)\right)^{R_{i}}\left(\frac{1}{2}-\eta \mu+\chi \eta\left(r_{i}-e_{1}^{*}\right)\right)^{1-R_{i}}
\end{aligned}
$$

where we substituted in equation (5) and as we derived above, $e_{1}^{*}=\gamma\left[1-\beta \chi \eta\left(\frac{\gamma}{2}+E\right)\right]$. If the mayor is in his second term, then the likelihood is given by

$$
\begin{aligned}
L\left(r_{i}, R_{i} \mid t_{i}=2, \theta\right) & =f\left(r_{i} \mid t_{i}=2, \theta\right) \\
& =\left(\frac{1}{2}+\eta \mu-\chi \eta\left(r_{i}-\gamma\right)\right) \phi\left(\frac{r_{i}-\gamma}{\sigma}\right) \frac{1}{\frac{1}{2}+\eta \mu}
\end{aligned}
$$

where the second line follows from Bayes' rule, and equations (3) and (5). We estimate the vector of parameters $\theta$ which maximizes the likelihood function:

$$
\mathscr{L}(r, R \mid t, \theta)=\prod_{i} L\left(r_{i}, R_{i} \mid t_{i}=2, \theta\right)^{1\left(t_{i}=2\right)} L\left(r_{i}, R_{i} \mid t_{i}=1, \theta\right)^{1\left(t_{i}=1\right)}
$$

The parameter $\chi$ is identified by the responsiveness of the reelection rate to the amount of rents revealed by first term mayors. The mean popularity shock $\mu$ is identified by the reelection rate. The technology of rent extraction $\gamma$ and the ability shock on rents $\sigma^{2}$ are identified by the moments of the rent distributions. ${ }^{20}$

\subsection{Results}

Parameter estimates. Table 10, Panel A reports the estimates of the structural parameters. We find that the probability of rents being revealed to voters is statistically indistinguishable from zero for both the control and treatment groups. This result is consistent with the reduced-form results presented earlier where we found no evidence for a link between reelection rates and corruption uncovered by audits after 2004. Since the estimate of the probability of rents being revealed is similar in both treatment and control groups, voter monitoring is unlikely to explain why rents are lower in treated municipalities. In contrast, rent extraction efficiency is significantly lower

\footnotetext{
${ }^{20}$ Since we do not find evidence for entry in section 5, we assume that the pool of candidates is fixed, allowing $\gamma$ to be identified.
} 
in the treatment group. The difference in the estimates for $\gamma$ in the treatment and control groups is statistically significant at the 10 percent level in a likelihood ratio test $\left(\chi_{1}^{2}=2.89, p=0.089\right)$. Furthermore, the estimates for the standard deviation of ability and the mean incumbent shock are larger in the treatment group, but neither of these two increases is statistically significant. Using a likelihood ratio test, we reject the hypothesis that the structural parameters are equal in the treatment and control groups $\left(\chi_{4}^{2}=13.73, p<0.01\right)$.

Equilibrium outcomes. Given the estimated parameters, we estimate some measures of interest and report them in Table 10, Panel B. Estimates for expected first term rents decrease from 4.02 in control to 3.88 in treated municipalities. Estimates for second term rents similarly decrease from 4.04 to 3.88. We break down these differences into the three channels: electoral discipline, non-electoral discipline and political selection.

The decrease in first-term rents is broken down into two channels (see equation (6)). Electoral discipline refers to the difference in rents between treatment and control which are caused by the change in reelection incentives. Non-electoral discipline refers to the residual change in first term rents between treatment and control. In the model, this difference is caused solely by a change in the mayor's rent extraction costs. We find that the decrease in first-term rents is entirely explained by the increase in non-electoral discipline. Furthermore, the change in rents due to electoral discipline is found to be insignificant.

We also separate the decrease in second-term rents into two channels. The first channel is political selection, which is the change in rents due to the change in the distribution of types which are reelected into a second term. The second channel, non-electoral discipline, is again given by the residual change in rents, which is due to the change in rent extraction costs. We find that the decrease in second period rents is entirely due to the change in non-electoral discipline. The difference in rents due to selection is a precisely estimated zero. In sum, the structural results are consistent with the hypothesis that rents are lower in previously audited municipalities because non-electoral discipline increases. We do not find evidence that electoral discipline or political selection are responsible for the decrease in corruption.

Simulations. We parameterize the model with the estimates reported in Table 10 for the control municipalities and conduct a number of policy simulations, which we report in Table $11 .^{21} \mathrm{We}$ first simulate changes in the probability that rents are detected by the electorate. For example, this could be caused by the CGU increasing the frequency of audit lotteries or the number of municipalities audited in each lottery. Alternatively, this could occur if, conditional on an audit,

\footnotetext{
${ }^{21}$ We find very similar results when parameterizing the model with the treatment estimates.
} 
the CGU increased its efforts in uncovering corruption and disseminating it to voters. We find that increasing the probability of detection reduces first-term rents significantly more rapidly than second-term rents. For example, a 5 percentage point increase in the detection rate leads to a 9 percent decrease in first-term rents and a 1 percent decrease in second-term rents. This result is also consistent with Ferraz and Finan (2011), who found that first-term mayors were significantly less corrupt than second-term mayors when the audit policy first began prior to the 2004 election.

Second, we simulate changes in $\gamma$, which reflect changes in non-electoral costs. $^{22}$ In practice, non-electoral costs could be increased if, for example, conviction rates conditional on corruption uncovered in audits increased. In the simulations, we find that first-term and second-term rents decrease proportionally by the same amounts when $\gamma$ decreases. For instance, reducing $\gamma$ by 5 percent leads to approximately 20 percent decreases in rents in both terms. Thus, according to our parameter estimates, in order to reduce the corruption of term-limited mayors, it is more effective to increase non-electoral costs than to attempt to improve selection through elections.

Finally, we simulate increases in ego rents, $E$. Suppose that mayoral wages increased by the amount that the average mayor already extracts through rents, holding the pool of potential candidates constant. We find that this increase in ego rents only decreases first-term rents by 3 percent, from 4.02 to $3.99 \log$ acts of corruption. Thus, unless such a policy induced significant changes in the pool of candidates, the simulations suggest that because of limited political accountability, increasing the value of office is unlikely to be an effective way to curb corruption.

\section{Conclusions}

This paper shows that the use of anti-corruption audits can be an effective policy in the fight against corruption. We find that corruption is 8 percent lower in places that have been audited in the past compared to municipalities that have not been audited. Naturally, this estimated impact captures only partial equilibrium effects. In the presence of spillovers, our estimates are likely to represent underestimates of the true impact, and we provide some evidence of this by showing that corruption is lower in municipalities where a neighbor was audited and local media is present to diffusive the information. We also show that audits increase the legal actions taken against corrupt mayors by increasing the chances of a police crackdown or a conviction in court.

\footnotetext{
${ }^{22}$ According to the model, we would find similar results by improving the mean ability of candidates running for office.
} 
By highlighting how audits can help spur legal sanctions, our findings offer important policy implications. While the existing literature has shown that information obtained through audits can help promote electoral accountability, this channel alone might not be sufficient to reduce corruption in the long run, especially if in response, public officials are able to adjust their electoral strategies or find alternative forms of corruption (Bobonis et al. (2015), Olken and Pande (2012)). A sustainable reduction in corruption may instead require policies aimed at improving the state's capacity to detect and prosecute corrupt politicians (e.g. Besley and Persson (2011)). Our results suggest that channeling resources to anti-corruption agencies who can implement well-executed random audits may be an important step towards this direction.

Although we have emphasized the importance of legal accountability for reducing political corruption, our understanding of how best to improve a country's legal system remains limited, particularly in a context where corruption is endemic. More research is needed to better understand how we can improve the selection of public prosecutors and judges, and the incentives they face to punish corrupt politicians.

\section{References}

Alt, J. E. and Lassen, D. D. (2008). Political And Judicial Checks on Corruption: Evidence from American State Governments. Economics and Politics, 20(1):33-61.

Aruoba, S. B., Drazen, A., and Vlaicu, R. (2015). A Structural Model of Electoral Accountability. NBER Working Papers 21151, National Bureau of Economic Research, Inc.

Ashworth, S. (2012). Electoral Accountability: Recent Theoretical and Empirical Work. Annual Review of Political Science, 15:183-201.

Bandiera, O., Prat, A., and Valletti, T. (2009). Active and Passive Waste in Government Spending: Evidence from a Policy Experiment. American Economic Review, 99(4):1278-1308.

Becker, G. (1968). Crime and Punishment: An Economic Approach. Journal of Political Economy, 76.

Becker, G. and Stigler, G. (1974). Law enforcement, malfeasance, and compensation of enforcers. The Journal of Legal Studies, 3(1):1-18.

Besley, T. (2007). Principled Agents?: The Political Economy of Good Government. Number 9780199283910 in OUP Catalogue. Oxford University Press. 
Besley, T. and Case, A. (1995). Does Electoral Accountability Affect Economic Policy Choices? Evidence from Gubernatorial Term Limits. The Quarterly Journal of Economics, 110(3):769-98.

Besley, T. and Persson, T. (2011). Pillars of Prosperity: The Political Economics of Development Clusters. Princeton University Press.

Bobonis, G. J., Camara Fuertes, L. R., and Schwabe, R. (2015). Monitoring Corruptible Politicians. American Economic Review, Forthcoming.

Brollo, F., Nannicini, T., Perotti, R., and Tabellini, G. (2013). The political resource curse. American Economic Review, 103(5):1759-96.

de Janvry, A., Finan, F., and Sadoulet, E. (2012). Local Electoral Incentives and Decentralized Program Performance. The Review of Economics and Statistics, 94(3):672-685.

Di Tella, R. and Schargrodsky, E. (2003). The Role of Wages and Auditing during a Crackdown on Corruption in the City of Buenos Aires. Journal of Law and Economics, 46(1):269-92.

Ferraz, C. and Finan, F. (2008). Exposing Corrupt Politicians: The Effects of Brazil's Publicly Released Audits on Electoral Outcomes. The Quarterly Journal of Economics, 123(2):703-745.

Ferraz, C. and Finan, F. (2011). Electoral accountability and corruption: Evidence from the audits of local governments. American Economic Review, 101(4):1274-1311.

Fisman, R., Schulz, F., and Vig, V. (2014). The Private Returns to Public Office. Journal of Political Economy, 122(4):806 - 862.

Glaeser, E. L. and Goldin, C. (2006). Corruption and Reform: Introduction. In Corruption and Reform: Lessons from America's Economic History, NBER Chapters, pages 2-22. National Bureau of Economic Research, Inc.

Glaeser, E. L. and Shleifer, A. (2002). Legal Origins. The Quarterly Journal of Economics, 117(4):1193-1229.

Kleven, H. J., Knudsen, M. B., Kreiner, C. T., Pedersen, S., and Saez, E. (2011). Unwilling or Unable to Cheat? Evidence From a Tax Audit Experiment in Denmark. Econometrica, 79(3):651692.

La Porta, R., Lopez-de-Silanes, F., Pop-Eleches, C., and Shleifer, A. (2004). Judicial Checks and Balances. Journal of Political Economy, 112(2):445-470. 
Lichand, G., Lopes, M., and Medeiros, M. (2016). Is corruption good for your health? Working Paper.

List, J. A. and Sturm, D. M. (2006). How Elections Matter: Theory and Evidence from Environmental Policy. The Quarterly Journal of Economics, 121(4):1249-1281.

Litschig, S. and Zamboni, Y. (2015). Judicial Presence and Rent Extraction. Working Papers 796, Barcelona Graduate School of Economics.

Olken, B. A. (2007). Monitoring Corruption: Evidence from a Field Experiment in Indonesia. Journal of Political Economy, 115:200-249.

Olken, B. A. and Pande, R. (2012). Corruption in Developing Countries. Annual Review of Economics, 4(1):479-509.

Pande, R. (2008). Understanding political corruption in low income countries. volume 4, chapter 50, pages 3155-3184. Elsevier, 1 edition.

Rose-Ackerman, S. (1999). Corruption and Government: Causes, Consequences, and Reform. Corruption and Government: Causes, Consequences, and Reform. Cambridge University Press.

Winters, M. S. and Weitz-Shapiro, R. (2013). Lacking information or condoning corruption: When will voters support corrupt politicians? Comparative Politics, 45(4):418-436.

Zamboni, Y. and Litschig, S. (2015). Audit Risk and Rent Extraction: Evidence from a Randomized Evaluation in Brazil. Working Papers 554, Barcelona Graduate School of Economics. 


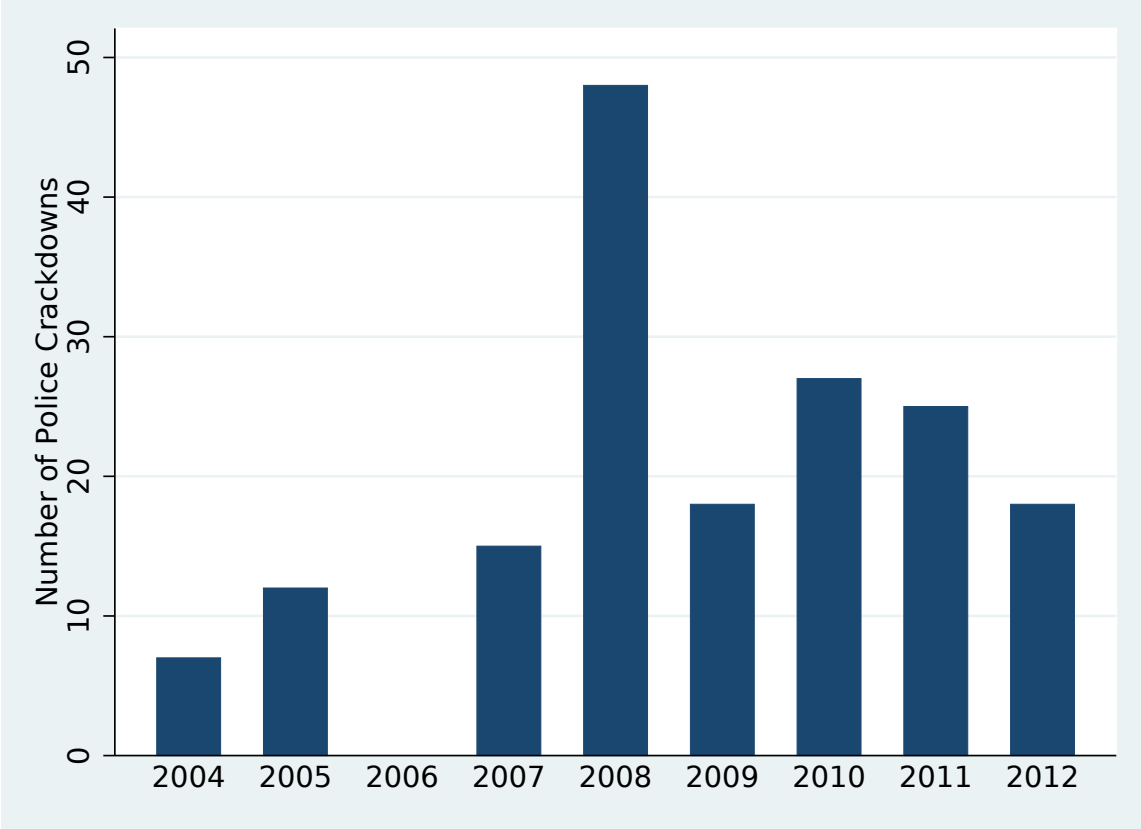

Panel A: Police Crackdowns

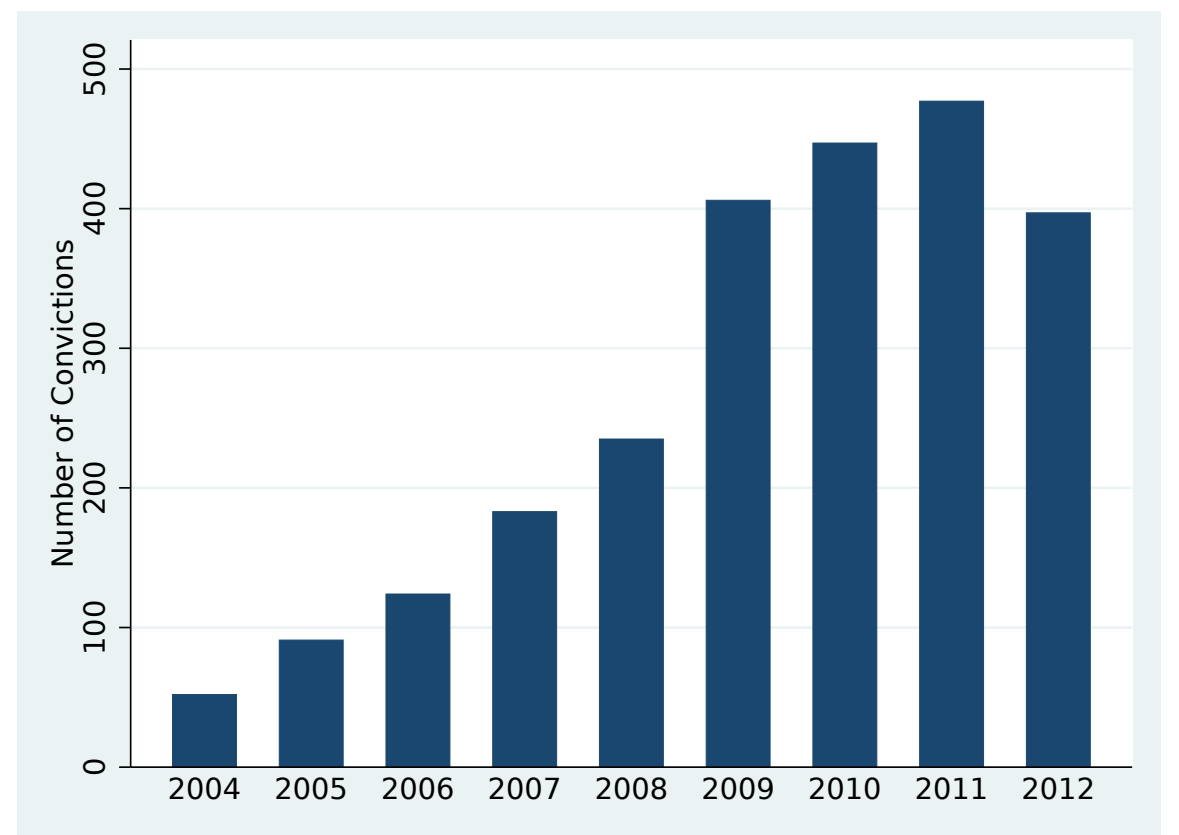

Panel B: Convictions

Figure 1: Number of Legal Actions over Time

Notes: This figures plots the number of convictions and police crackdowns involving political corruption during the period 2004 to 2012. 

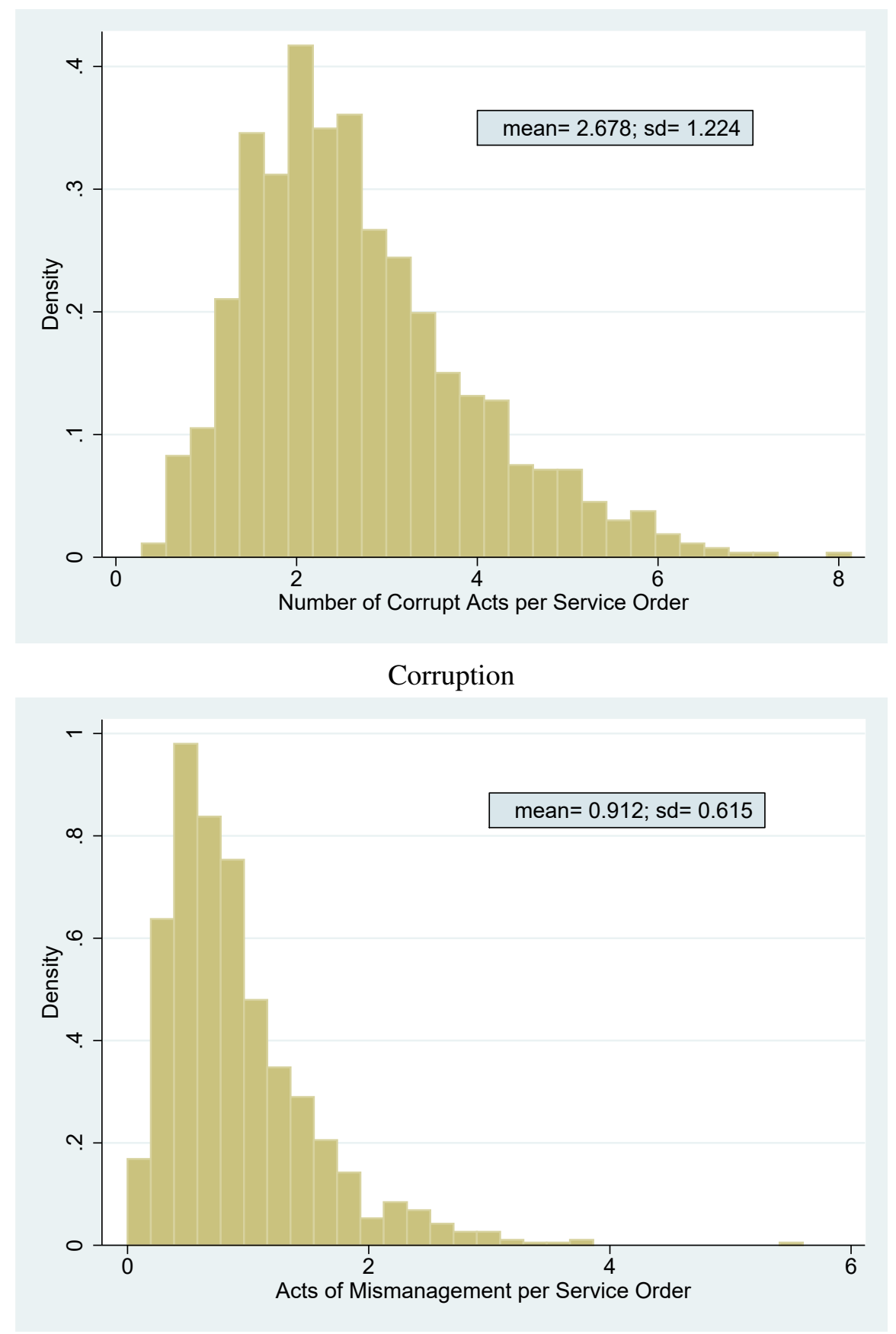

Mismanagement

Figure 2: Distribution of Irregularities Associated with Corruption and Mismanagement

Notes: This figure displays the distribution of irregularities per service order associated with corruption and mismanagement. These data are based on the audits conducted from lotteries 22 to 38. 


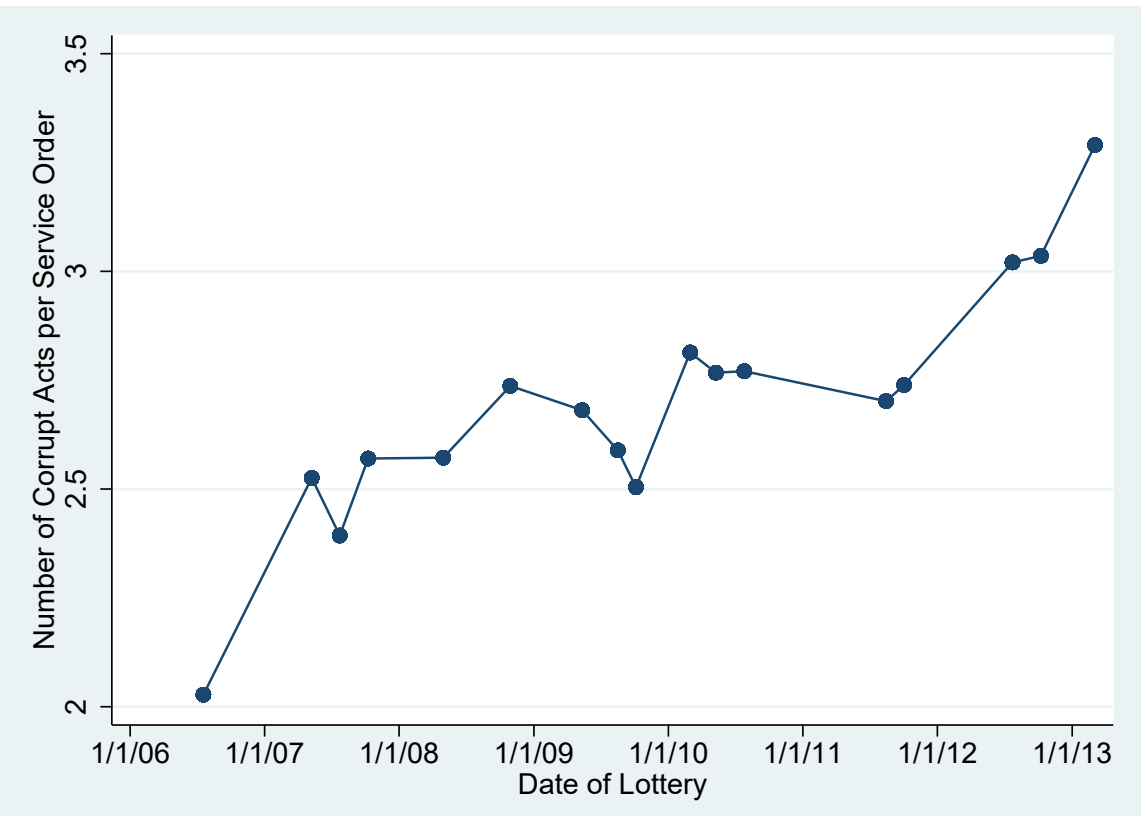

\section{Corruption}

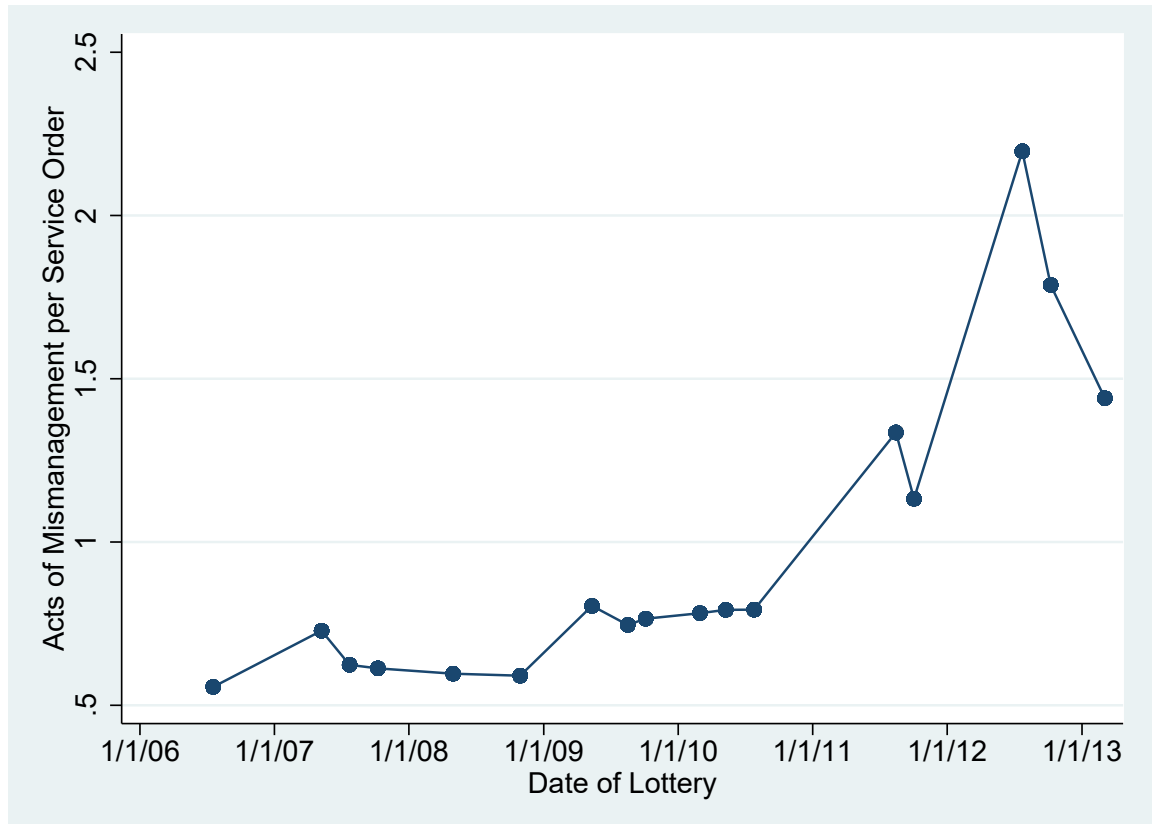

Mismanagement

Figure 3: Average Number of Irregularities By Lottery

Notes: This figure displays by lottery the average number of irregularities per service order associated with corruption or mismanagement. These data are based on the audits conducted in lotteries 22-38. 


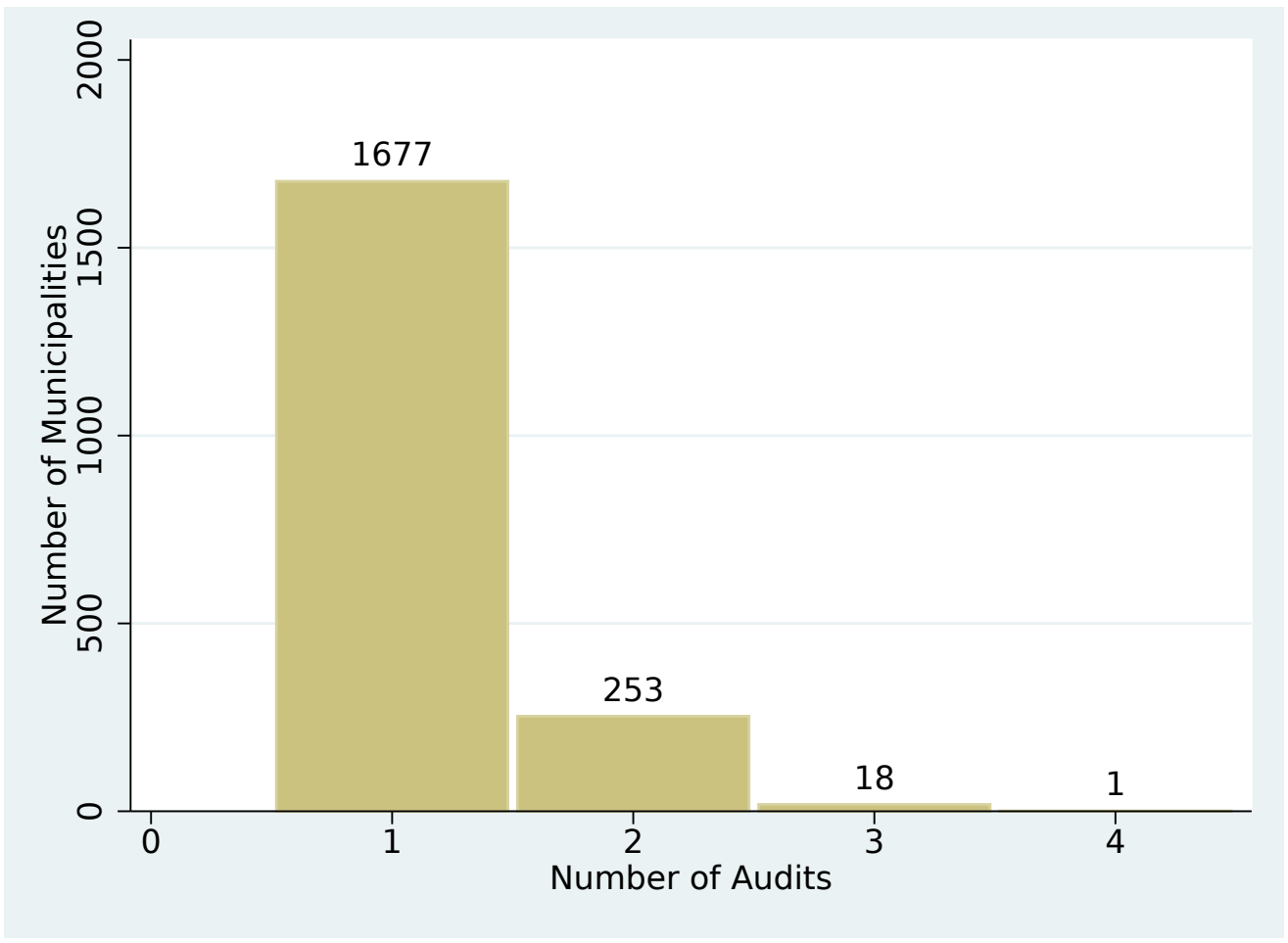

Figure 4: Distribution of Times a Municipality has been Audited

Notes: This figures plots the distribution of the number of times a municipality has been audited during the duration of the program. 


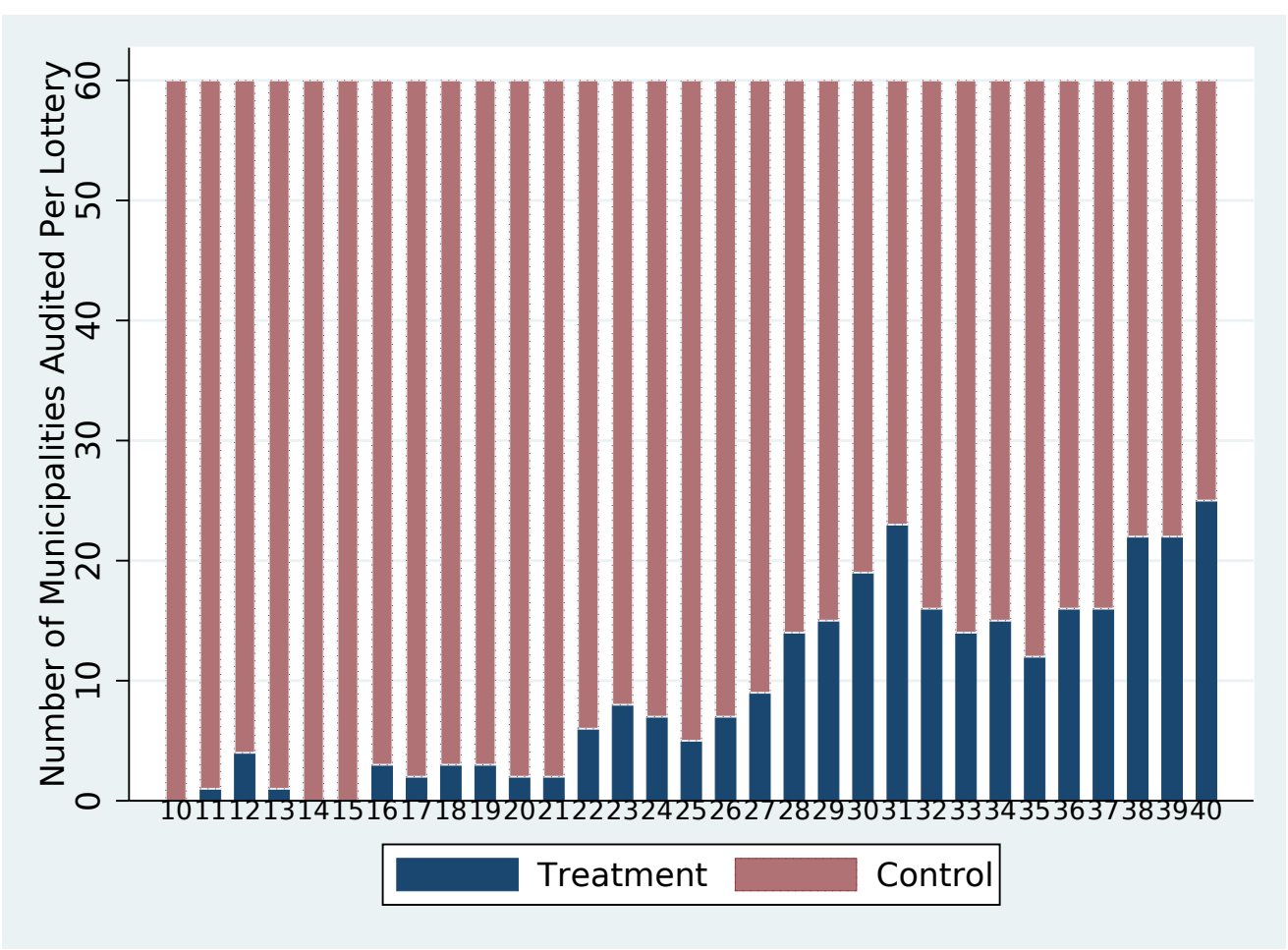

Figure 5: Distribution of Times a Municipality has been Audited

Notes: This figure plots the number of municipalities that had been audited in the past for a given lottery. The solid blue bars denote the number of treated municipalities (i.e. previously audited). The solid red bars denote the number of control municipalities. 
Table 1: Mean Comparisons Between Audited and Non-audited

\begin{tabular}{|c|c|c|c|c|c|}
\hline & \multicolumn{2}{|c|}{ Control } & \multicolumn{2}{|c|}{ Treatment } & \multirow[b]{2}{*}{$\begin{array}{c}\text { Difference } \\
\text { (5) }\end{array}$} \\
\hline & $\begin{array}{l}\text { Mean } \\
\text { (1) }\end{array}$ & $\begin{array}{l}\text { Std Dev. } \\
\text { (2) }\end{array}$ & $\begin{array}{l}\text { Mean } \\
\text { (3) }\end{array}$ & $\begin{array}{l}\text { Std Dev. } \\
\text { (4) }\end{array}$ & \\
\hline Population & 22992.720 & 45069.940 & 26000.850 & 43799.660 & $\begin{array}{c}436.700 \\
{[2553.579]}\end{array}$ \\
\hline Share female & 0.495 & 0.015 & 0.496 & 0.014 & $\begin{array}{c}0.000 \\
{[0.001]}\end{array}$ \\
\hline Share urban & 0.574 & 0.235 & 0.576 & 0.234 & $\begin{array}{c}0.008 \\
{[0.014]}\end{array}$ \\
\hline Human Development Index & 0.507 & 0.105 & 0.492 & 0.101 & $\begin{array}{c}-0.002 \\
{[0.004]}\end{array}$ \\
\hline Income inequality (Gini) & 0.550 & 0.068 & 0.563 & 0.069 & $\begin{array}{c}0.003 \\
{[0.005]}\end{array}$ \\
\hline Income per capita $(\log )$ & 5.575 & 0.580 & 5.499 & 0.582 & $\begin{array}{c}-0.001 \\
{[0.026]}\end{array}$ \\
\hline$\%$ Poor & 0.445 & 0.229 & 0.486 & 0.215 & $\begin{array}{c}0.502 \\
{[0.821]}\end{array}$ \\
\hline Share illiterate & 0.247 & 0.136 & 0.268 & 0.134 & $\begin{array}{c}0.303 \\
{[0.494]}\end{array}$ \\
\hline$\%$ bureaucracy with a college degree & 0.192 & 0.123 & 0.180 & 0.118 & $\begin{array}{c}-0.007 \\
{[0.006]}\end{array}$ \\
\hline$\%$ population with a colllege degree & 0.207 & 0.212 & 0.204 & 0.229 & $\begin{array}{c}0.009 \\
{[0.011]}\end{array}$ \\
\hline Has AM Radio & 0.211 & 0.408 & 0.243 & 0.430 & $\begin{array}{c}0.017 \\
{[0.032]}\end{array}$ \\
\hline Has a Judiciary District & 0.447 & 0.497 & 0.523 & 0.501 & $\begin{array}{c}0.002 \\
{[0.038]}\end{array}$ \\
\hline Effective Number Candidates for Mayor & 2.150 & 0.550 & 2.204 & 0.648 & $\begin{array}{c}0.044 \\
{[0.038]}\end{array}$ \\
\hline Reelection rates for Mayors & 0.405 & 0.491 & 0.437 & 0.497 & $\begin{array}{c}0.026 \\
{[0.048]}\end{array}$ \\
\hline Mayor's Years of Education & 12.009 & 4.194 & 11.868 & 4.355 & $\begin{array}{c}-0.229 \\
{[0.387]}\end{array}$ \\
\hline Share of Votes Mayor received & 0.561 & 0.125 & 0.564 & 0.133 & $\begin{array}{c}0.006 \\
{[0.010]}\end{array}$ \\
\hline Number of Service Orders & 25.205 & 9.264 & 24.802 & 9.983 & $\begin{array}{l}-0.169 \\
{[0.618]}\end{array}$ \\
\hline $\mathrm{N}$ & 881 & & 222 & & \\
\hline
\end{tabular}

Notes: This table shows means and standard deviations of various municipal characteristics by places that have been audited in the past (treatment) and places that have not been audited in the past (control). The difference and corresponding standard error (in brackets) are computed based on a regression that controls for both state and lottery fixed effects. All of these characteristics are based on information collected in 2000, except for the share of the bureaucracy with a college degree, which is based on a 2005 survey. 
Table 2: The Effects of the Audits on Corruption and Mismanagement

\begin{tabular}{|c|c|c|c|c|c|c|c|c|c|}
\hline & \multicolumn{3}{|c|}{ Number of Irregularities } & \multicolumn{3}{|c|}{ Acts of Mismanagement } & \multicolumn{3}{|c|}{ Acts of Corruptions } \\
\hline & $(1)$ & (2) & (3) & (4) & (5) & (6) & (7) & $(8)$ & (9) \\
\hline Audited in the past & $\begin{array}{c}-0.034 \\
{[0.021]}\end{array}$ & $\begin{array}{l}-0.045+ \\
{[0.022]}\end{array}$ & $\begin{array}{l}-0.058^{*} \\
{[0.021]}\end{array}$ & $\begin{array}{c}0.010 \\
{[0.052]}\end{array}$ & $\begin{array}{c}0.001 \\
{[0.048]}\end{array}$ & $\begin{array}{c}-0.023 \\
{[0.041]}\end{array}$ & $\begin{array}{l}-0.059^{*} \\
{[0.024]}\end{array}$ & $\begin{array}{l}-0.070^{*} \\
{[0.025]}\end{array}$ & $\begin{array}{l}-0.079 * \\
{[0.027]}\end{array}$ \\
\hline Population (log) & & $\begin{array}{l}0.057^{*} \\
{[0.011]}\end{array}$ & $\begin{array}{l}0.064 * \\
{[0.012]}\end{array}$ & & $\begin{array}{l}0.047^{*} \\
{[0.015]}\end{array}$ & $\begin{array}{l}0.037+ \\
{[0.021]}\end{array}$ & & $\begin{array}{l}0.053^{*} \\
{[0.015]}\end{array}$ & $\begin{array}{l}0.064^{*} \\
{[0.018]}\end{array}$ \\
\hline Income inequality (Gini) & & $\begin{array}{c}0.337 * \\
{[0.111]}\end{array}$ & $\begin{array}{c}0.361 * \\
{[0.112]}\end{array}$ & & $\begin{array}{c}0.137 \\
{[0.295]}\end{array}$ & $\begin{array}{c}0.177 \\
{[0.249]}\end{array}$ & & $\begin{array}{l}0.449 * \\
{[0.158]}\end{array}$ & $\begin{array}{c}0.459 * \\
{[0.177]}\end{array}$ \\
\hline Income per capita $(\log )$ & & $\begin{array}{l}-0.085 \\
{[0.056]}\end{array}$ & $\begin{array}{l}-0.102 * \\
{[0.045]}\end{array}$ & & $\begin{array}{c}0.111 \\
{[0.086]}\end{array}$ & $\begin{array}{c}0.103 \\
{[0.087]}\end{array}$ & & $\begin{array}{l}-0.158 * \\
{[0.064]}\end{array}$ & $\begin{array}{l}-0.176^{*} \\
{[0.059]}\end{array}$ \\
\hline Illiteracy & & $\begin{array}{c}0.003 \\
{[0.002]}\end{array}$ & $\begin{array}{c}0.003^{*} \\
{[0.001]}\end{array}$ & & $\begin{array}{c}0.001 \\
{[0.003]}\end{array}$ & $\begin{array}{c}0.000 \\
{[0.002]}\end{array}$ & & $\begin{array}{l}0.004 * \\
{[0.002]}\end{array}$ & $\begin{array}{c}0.005^{*} \\
{[0.002]}\end{array}$ \\
\hline Share of urban population & & $\begin{array}{l}0.123+ \\
{[0.067]}\end{array}$ & $\begin{array}{l}0.118^{*} \\
{[0.045]}\end{array}$ & & $\begin{array}{l}-0.056 \\
{[0.091]}\end{array}$ & $\begin{array}{l}-0.068 \\
{[0.136]}\end{array}$ & & $\begin{array}{l}0.190 * \\
{[0.086]}\end{array}$ & $\begin{array}{l}0.182 * \\
{[0.058]}\end{array}$ \\
\hline $\begin{array}{l}\text { Controls } \\
\text { f(Service Orders) }\end{array}$ & $\begin{array}{c}\mathrm{N} \\
\log \end{array}$ & $\begin{array}{c}\mathrm{Y} \\
\log \end{array}$ & $\begin{array}{c}\mathrm{Y} \\
\text { nonpar }\end{array}$ & $\begin{array}{c}\mathrm{N} \\
\log \end{array}$ & $\begin{array}{c}\mathrm{Y} \\
\log \end{array}$ & $\begin{array}{c}\mathrm{Y} \\
\text { nonpar }\end{array}$ & $\begin{array}{c}\mathrm{N} \\
\log \end{array}$ & $\begin{array}{c}\mathrm{Y} \\
\log \end{array}$ & $\begin{array}{c}\mathrm{Y} \\
\text { nonpar }\end{array}$ \\
\hline$R^{2}$ & 0.414 & 0.449 & 0.539 & 0.364 & 0.374 & 0.434 & 0.303 & 0.337 & 0.483 \\
\hline $\mathrm{N}$ & 983 & 983 & 983 & 983 & 983 & 983 & 983 & 983 & 983 \\
\hline
\end{tabular}

Notes: This table reports the effects of being audited in the past on corruption and mismanagement. The dependent variable in columns 1-3 is the total number of irregularities discovered in the audit. In columns 4-6, the dependent variable is the log of total acts of mismanagement, and in columns 7-9 the dependent variable is the $\log$ of total acts of corruption. In addition to the controls presented in the table, each regression controls for state and lottery fixed effects. In columns $3,6,9$ the number of service items audited is controlled for in a fully nonparametric fashion. In the other columns, we control for the log of the number of service items audited. Robust standard errors are reported in brackets, $+\mathrm{p}<0.10,{ }^{*} \mathrm{p}<0.05$. 
Table 3: Spillover Effects of Neighboring Audits on Acts of Corruption

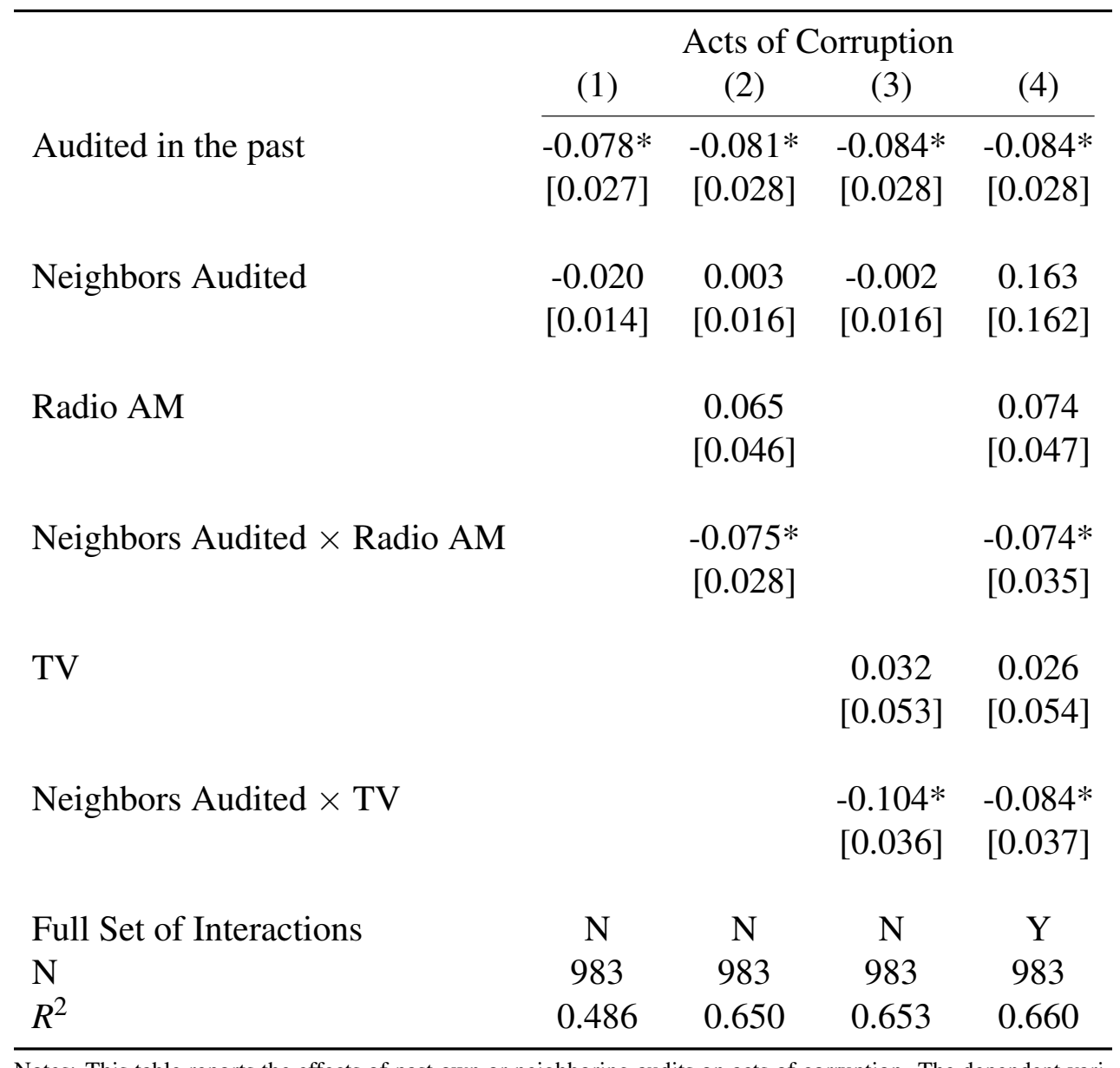

Notes: This table reports the effects of past own or neighboring audits on acts of corruption. The dependent variable is the log of the total acts of corruption discovered in the audit. In addition to the municipal controls presented in Table 2, each regression controls for state, lottery, service order, and number of neighbors fixed effects. In column 4, we interact Neighbors Audited with the full set of municipal controls. Robust standard errors are reported in brackets, $+\mathrm{p}<0.10, * \mathrm{p}<0.05$ 
Table 4: The Effects of the Audits on Legal Actions

\begin{tabular}{|c|c|c|c|c|c|c|c|c|c|}
\hline & \multicolumn{2}{|c|}{ Crackdowns } & \multicolumn{2}{|c|}{ Convictions } & \multicolumn{2}{|c|}{ Legal Action } & \multirow{2}{*}{$\begin{array}{c}\text { Crackdowns } \\
\text { (7) }\end{array}$} & \multirow{2}{*}{$\begin{array}{c}\text { Convictions } \\
\text { (8) }\end{array}$} & \multirow{2}{*}{$\begin{array}{c}\text { Legal Action } \\
\text { (9) }\end{array}$} \\
\hline & (1) & (2) & (3) & (4) & $(5)$ & (6) & & & \\
\hline Audited & $\begin{array}{c}0.00139 \\
(0.001)\end{array}$ & $\begin{array}{c}-0.0000887 \\
(0.001)\end{array}$ & $\begin{array}{c}0.00443+ \\
(0.002)\end{array}$ & $\begin{array}{c}0.000195 \\
(0.003)\end{array}$ & $\begin{array}{c}0.00562 * \\
(0.003)\end{array}$ & $\begin{array}{c}0.000241 \\
(0.003)\end{array}$ & & & \\
\hline Audit $\times$ Judiciary District & & $\begin{array}{c}0.00325+ \\
(0.002)\end{array}$ & & $\begin{array}{c}0.00933^{*} \\
(0.004)\end{array}$ & & $\begin{array}{c}0.0119 * \\
(0.005)\end{array}$ & & & \\
\hline Corruption (logs) & & & & & & & $\begin{array}{c}0.0369+ \\
(0.021)\end{array}$ & $\begin{array}{c}0.0601 * \\
(0.029)\end{array}$ & $\begin{array}{c}0.0882 * \\
(0.035)\end{array}$ \\
\hline Mismanagement $(\log s)$ & & & & & & & $\begin{array}{c}-0.0116 \\
(0.016)\end{array}$ & $\begin{array}{c}-0.00647 \\
(0.02)\end{array}$ & $\begin{array}{c}-0.0146 \\
(0.024)\end{array}$ \\
\hline Control group mean & 0.003 & 0.024 & 0.027 & 0.003 & 0.024 & 0.027 & 0.047 & 0.202 & 0.240 \\
\hline $\mathrm{N}$ & 70,902 & 70,902 & 70,902 & 70,902 & 70,902 & 70,902 & 982 & 982 & 982 \\
\hline
\end{tabular}

Notes: This table investigate the effects of the audits on the occurrence of a legal action. In columns 1, 2 and 7, the dependent variable is whether a police crackdown on political corruption was conducted in the municipality in a given year. In columns 3, 4, and 8, the dependent variable is whether a mayor was prosecuted for corruption in a given year. In columns 5,6 and 9 , the dependent variable is whether a police investigation or a conviction occurred. Each regression controls for our set of municipal controls. Robust standard errors are reported in brackets, $+\mathrm{p}<0.10, * \mathrm{p}<0.05$. 
Table 5: The Effects of the Audits on Corruption

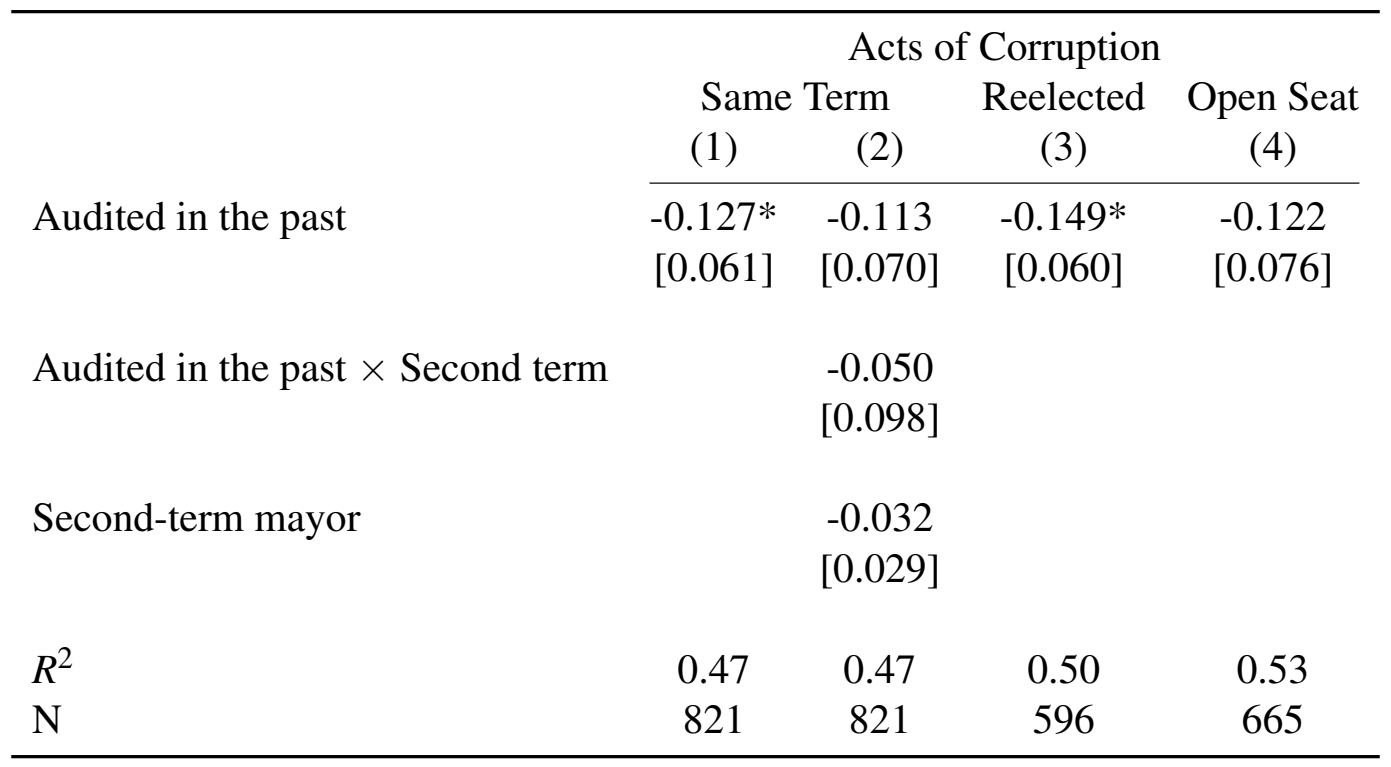

Notes: This table reports the effects of being audited in the past on corruption. The dependent variable is the log of the total acts of corruption discovered in the audit. In addition to the municipal controls presented in 2, each regression controls for state, lottery, service order fixed effects. Robust standard errors are reported in brackets, $+p<0.10, * p<0.05$. 
Table 6: The Effects of the Audits on Entry

\begin{tabular}{|c|c|c|c|c|c|c|c|c|c|c|}
\hline & \multirow[b]{2}{*}{$\begin{array}{c}\text { Win } \\
\text { Margin } \\
\text { (1) }\end{array}$} & \multirow[b]{2}{*}{$\begin{array}{c}\text { Number of } \\
\text { Candidates } \\
\text { (2) }\end{array}$} & \multirow[b]{2}{*}{$\begin{array}{l}\text { Number of } \\
\text { Parties } \\
\text { (3) }\end{array}$} & \multicolumn{4}{|c|}{ Characteristics of the Candidate Pool } & \multicolumn{3}{|c|}{ Mayor Characteristics } \\
\hline & & & & $\begin{array}{c}\text { Elementary } \\
\text { School } \\
(4)\end{array}$ & $\begin{array}{l}\text { High } \\
\text { School } \\
(5)\end{array}$ & $\begin{array}{c}\text { College } \\
\text { (6) }\end{array}$ & $\begin{array}{c}\text { Campaign } \\
\text { Spending } \\
(7)\end{array}$ & $\begin{array}{l}\text { White } \\
\text { Collar } \\
(8)\end{array}$ & $\begin{array}{c}\text { Male } \\
(9)\end{array}$ & $\begin{array}{c}\text { College } \\
(10)\end{array}$ \\
\hline Audited in the past & $\begin{array}{c}0.010 \\
{[0.020]}\end{array}$ & $\begin{array}{c}-0.002 \\
{[0.029]}\end{array}$ & $\begin{array}{c}0.000 \\
{[0.028]}\end{array}$ & $\begin{array}{c}-0.024 \\
{[0.023]}\end{array}$ & $\begin{array}{c}0.026 \\
{[0.028]}\end{array}$ & $\begin{array}{c}0.000 \\
{[0.028]}\end{array}$ & $\begin{array}{l}-0.018 \\
{[0.068]}\end{array}$ & $\begin{array}{c}-0.009 \\
{[0.043]}\end{array}$ & $\begin{array}{c}-0.027 \\
{[0.030]}\end{array}$ & $\begin{array}{c}0.030 \\
{[0.047]}\end{array}$ \\
\hline$R^{2}$ & 0.07 & 0.30 & 0.31 & 0.15 & 0.23 & 0.21 & 0.65 & 0.24 & 0.11 & 0.12 \\
\hline $\mathrm{N}$ & 665 & 684 & 684 & 684 & 684 & 684 & 672 & 662 & 679 & 685 \\
\hline
\end{tabular}

Notes: This table reports the effects of being audited on the candidate pool. The dependent variable is specified at the top of each column. The number of candidates, number of parties, and campaign spending are measured in logs. In addition to the municipal controls presented in 2, each regression controls election and state fixed effects. The sample is restricted to open-seat elections. Robust standard errors clustered at the municipality level are reported in brackets, $+\mathrm{p}<0.10, * \mathrm{p}<0.05$. 
Table 7: The Effects of the Audits on Displacement

\begin{tabular}{|c|c|c|c|c|c|c|c|}
\hline & \multicolumn{3}{|c|}{ Full Sample } & \multicolumn{3}{|c|}{ Same Term } & \multirow[b]{2}{*}{$\begin{array}{c}\text { Acts of } \\
\text { Corruption } \\
(7)\end{array}$} \\
\hline & $\begin{array}{c}\text { Embezzlement } \\
\text { (1) }\end{array}$ & $\begin{array}{l}\text { Procurement } \\
\text { (2) }\end{array}$ & $\begin{array}{c}\text { Over- } \\
\text { invoicing } \\
(3)\end{array}$ & $\begin{array}{c}\text { Embezzlement } \\
\text { (4) }\end{array}$ & $\begin{array}{c}\text { Procurement } \\
\text { (5) }\end{array}$ & $\begin{array}{c}\text { Over- } \\
\text { invoicing } \\
(6)\end{array}$ & \\
\hline Audited in the past & $\begin{array}{c}0.031 \\
{[0.084]}\end{array}$ & $\begin{array}{c}0.011 \\
{[0.060]}\end{array}$ & $\begin{array}{c}-0.026 \\
{[0.029]}\end{array}$ & $\begin{array}{c}-0.132 \\
{[0.128]}\end{array}$ & $\begin{array}{c}0.117 \\
{[0.103]}\end{array}$ & $\begin{array}{c}-0.050 \\
{[0.061]}\end{array}$ & \\
\hline Share of same sectors audited & & & & & & & $\begin{array}{c}0.200 \\
{[0.266]}\end{array}$ \\
\hline$R^{2}$ & 0.13 & 0.21 & 0.03 & 0.14 & 0.21 & 0.04 & 0.69 \\
\hline $\mathrm{N}$ & 983 & 983 & 983 & 821 & 821 & 821 & 217 \\
\hline
\end{tabular}


Table 8: The Effects of Audits on Public Spending

\begin{tabular}{|c|c|c|c|c|c|c|c|}
\hline & $\begin{array}{l}\text { Education } \\
\text { (1) }\end{array}$ & $\begin{array}{l}\text { Health } \\
\text { (2) }\end{array}$ & $\begin{array}{c}\text { Administration } \\
\text { (3) }\end{array}$ & $\begin{array}{l}\text { Housing } \\
\text { (4) }\end{array}$ & $\begin{array}{c}\text { Welfare } \\
\text { (5) }\end{array}$ & $\begin{array}{c}\text { Transportation } \\
\text { (6) }\end{array}$ & $\begin{array}{l}\text { Other } \\
(7)\end{array}$ \\
\hline Audited in the past & $\begin{array}{c}-0.006 \\
{[0.006]}\end{array}$ & $\begin{array}{c}-0.006 \\
{[0.005]}\end{array}$ & $\begin{array}{c}0.009 \\
{[0.008]}\end{array}$ & $\begin{array}{c}0.005 \\
{[0.005]}\end{array}$ & $\begin{array}{c}0.000 \\
{[0.003]}\end{array}$ & $\begin{array}{c}-0.004 \\
{[0.003]}\end{array}$ & $\begin{array}{c}0.001 \\
{[0.004]}\end{array}$ \\
\hline$R^{2}$ & 0.598 & 0.235 & 0.204 & 0.290 & 0.275 & 0.502 & 0.421 \\
\hline $\mathrm{N}$ & 773 & 773 & 773 & 773 & 773 & 773 & 773 \\
\hline
\end{tabular}


Table 9: The Effects of the Audits on Federal Block Grants

\begin{tabular}{lccc}
\hline & $\begin{array}{c}\text { Number of } \\
\text { Block Grants } \\
(1)\end{array}$ & $\begin{array}{c}\text { Amount of } \\
\text { Block Grants } \\
\text { Audited in the past }\end{array}$ & $\begin{array}{c}\text { Share of } \\
\text { Funds Disbursed } \\
(3)\end{array}$ \\
\cline { 2 - 4 } & -0.027 & -0.053 & 0.018 \\
& {$[0.050]$} & {$[0.077]$} & {$[0.018]$} \\
$R^{2}$ & & & \\
$\mathrm{~N}$ & 0.55 & 0.42 & 0.34 \\
\hline
\end{tabular}

Notes: This table reports the effects of being audited in the past on the amount of blocks grants the municipality received in the subsequent years of the administration. The dependent variables in columns 1 and 2 are expressed in logs. In addition to the municipal controls presented in 2, each regression controls for state, lottery, service order fixed effects. Robust standard errors are reported in brackets, $+\mathrm{p}<0.10,{ }^{*} \mathrm{p}<0.05$. 
Table 10: Structural Estimates

\begin{tabular}{|c|c|c|}
\hline & $\begin{array}{l}\text { Control } \\
\text { (1) }\end{array}$ & $\begin{array}{l}\text { Treatment } \\
\text { (2) }\end{array}$ \\
\hline \multicolumn{3}{|l|}{ Panel A: Parameter estimates } \\
\hline Probability rents revealed $(\chi)$ & $\begin{array}{c}0.01 \\
{[0.03]}\end{array}$ & $\begin{array}{l}0.001 \\
{[0.05]}\end{array}$ \\
\hline Rent extraction efficiency $(\gamma)$ & $\begin{array}{c}4.04 \\
{[0.04]}\end{array}$ & $\begin{array}{c}3.88 \\
{[0.07]}\end{array}$ \\
\hline Standard deviation of ability $(\sigma)$ & $\begin{array}{c}0.36 \\
{[0.02]}\end{array}$ & $\begin{array}{c}0.42 \\
{[0.03]}\end{array}$ \\
\hline Mean incumbent popularity shock $(\mu)$ & $\begin{array}{l}-0.56 \\
{[0.17]}\end{array}$ & $\begin{array}{l}-0.32 \\
{[0.24]}\end{array}$ \\
\hline \multicolumn{3}{|l|}{ Panel B: Equilibrium outcomes } \\
\hline Expected first term rents & $\begin{array}{c}4.02 \\
{[0.03]}\end{array}$ & $\begin{array}{c}3.88 \\
{[0.06]}\end{array}$ \\
\hline Expected second term rents & $\begin{array}{c}4.04 \\
{[0.04]}\end{array}$ & $\begin{array}{c}3.88 \\
{[0.07]}\end{array}$ \\
\hline $\begin{array}{l}\text { Change in first-term rents } \\
\text { - due to electoral discipline }\end{array}$ & \multicolumn{2}{|c|}{$\begin{array}{l}-0.01 \\
{[0.09]}\end{array}$} \\
\hline - due to non-electoral discipline & \multicolumn{2}{|c|}{$\begin{array}{l}-0.16 \\
{[0.09]}\end{array}$} \\
\hline $\begin{array}{l}\text { Change in second-term rents } \\
\text { - due to selection }\end{array}$ & \multicolumn{2}{|c|}{$\begin{array}{c}0.00 \\
{[0.01]}\end{array}$} \\
\hline - due to non-electoral discipline & \multicolumn{2}{|c|}{$\begin{array}{l}-0.16 \\
{[0.09]}\end{array}$} \\
\hline
\end{tabular}

Notes: Standard errors in brackets. The log-likelihood is -267. Rents are measured by the log of total acts of corruption compiled by the CGU. The sample consists of 319 audits from the last two years of the 2009-2012 mayoral term. Treated muncipalities are those that have been previously audited and control municipalities are those audited for the first time. The annual discount rate is set to $4 \%$. Ego rents are set to 0 . The estimates are also adjusted for lottery and state fixed effects. 
Table 11: Simulations

\begin{tabular}{cc}
\multicolumn{2}{c}{ Expected rents } \\
First-term & Second-term \\
(1) & (2)
\end{tabular}

Variation in the probability of detection by voters

Baseline $(\chi=0.01)$

$4.02 \quad 4.04$

5 percentage point increase

3.93

4.03

10 percentage point increase

3.85

4.03

Variation in the efficiency of rent extraction

Baseline $(\gamma=4.04)$

4.02

4.04

5 percent decrease

3.82

3.83

10 percent decrease

3.62

3.63

Variation in ego rents

Baseline $(E=0)$

4.02

4.04

Ego rents equal to 4 (average rents)

3.99

4.04

Ego rents equal to 8 (double average rents)

3.95

4.04

Notes: Expected rents are measured by the log of total acts of corruption compiled by the CGU. The baseline estimates are those obtained for the sample of control municipalities in Table 10. See the notes of that table for more details. 


\section{A Appendix A}

Table A.1: Audit Probabilities

\begin{tabular}{ll}
\hline Acre & 0.019 \\
Alagoas & 0.014 \\
Amapá & 0.019 \\
Amazonas & 0.016 \\
Bahia & 0.011 \\
Ceará & 0.016 \\
Espírito Santo & 0.013 \\
Goiás & 0.011 \\
Maranhão & 0.011 \\
Mato Grosso & 0.013 \\
Mato Grosso do Sul & 0.016 \\
Minas Gerais & 0.008 \\
Paraná & 0.008 \\
Paraíba & 0.011 \\
Pará & 0.019 \\
Pernambuco & 0.014 \\
Piauí & 0.011 \\
Rio Grande do Norte & 0.015 \\
Rio Grande do Sul & 0.009 \\
Rio de Janeiro & 0.023 \\
Rondônia & 0.019 \\
Roraima & 0.019 \\
Santa Catarina & 0.008 \\
Sergipe & 0.018 \\
São Paulo & 0.008 \\
Tocantins & 0.011 \\
Total & \\
\hline & 0.013 \\
\hline
\end{tabular}

Notes: This table shows the ex-ante probability of being audited by state. 
Table A.2: The Effects of the Audits on Corruption and Mismanagement By Local Characteristics

\begin{tabular}{|c|c|c|c|c|c|c|c|c|c|c|}
\hline & \multicolumn{5}{|c|}{ Acts of Mismanagement } & \multicolumn{5}{|c|}{ Acts of Corruption } \\
\hline & {$[1]$} & {$[2]$} & [3] & [4] & {$[5]$} & {$[6]$} & {$[7]$} & [8] & [9] & {$[10]$} \\
\hline Audited in the past & $\begin{array}{l}-0.025 \\
{[0.041]}\end{array}$ & $\begin{array}{c}-0.024 \\
{[0.041]}\end{array}$ & $\begin{array}{c}-0.024 \\
{[0.040]}\end{array}$ & $\begin{array}{c}-0.023 \\
{[0.041]}\end{array}$ & $\begin{array}{c}-0.026 \\
{[0.043]}\end{array}$ & $\begin{array}{l}-0.077 * \\
{[0.027]}\end{array}$ & $\begin{array}{l}-0.080 * \\
{[0.028]}\end{array}$ & $\begin{array}{c}-0.085^{*} \\
{[0.030]}\end{array}$ & $\begin{array}{c}-0.079 * \\
{[0.028]}\end{array}$ & $\begin{array}{l}-0.082 * \\
{[0.028]}\end{array}$ \\
\hline Treatment Interacted with & & & & & & & & & & \\
\hline Radio & $\begin{array}{c}-0.038 \\
{[0.113]}\end{array}$ & & & & $\begin{array}{c}-0.061 \\
{[0.132]}\end{array}$ & $\begin{array}{c}-0.053 \\
{[0.078]}\end{array}$ & & & & $\begin{array}{c}-0.014 \\
{[0.078]}\end{array}$ \\
\hline Share of pop with a college degree & & $\begin{array}{c}0.001 \\
{[0.014]}\end{array}$ & & & $\begin{array}{c}0.004 \\
{[0.029]}\end{array}$ & & $\begin{array}{c}-0.018 \\
{[0.014]}\end{array}$ & & & $\begin{array}{c}-0.008 \\
{[0.019]}\end{array}$ \\
\hline Income per capita $(\log )$ & & & $\begin{array}{c}-0.011 \\
{[0.063]}\end{array}$ & & $\begin{array}{c}-0.054 \\
{[0.105]}\end{array}$ & & & $\begin{array}{c}-0.061 \\
{[0.052]}\end{array}$ & & $\begin{array}{c}-0.018 \\
{[0.078]}\end{array}$ \\
\hline Share of urban population & & & & $\begin{array}{c}0.091 \\
{[0.205]}\end{array}$ & $\begin{array}{c}0.191 \\
{[0.289]}\end{array}$ & & & & $\begin{array}{c}-0.159 \\
{[0.117]}\end{array}$ & $\begin{array}{c}-0.077 \\
{[0.124]}\end{array}$ \\
\hline P-value (Joint test) & & & & & 0.95 & & & & & 0.68 \\
\hline$R^{2}$ & 0.433 & 0.432 & 0.434 & 0.433 & 0.435 & 0.479 & 0.480 & 0.481 & 0.486 & 0.488 \\
\hline $\mathrm{N}$ & 983 & 983 & 983 & 983 & 983 & 983 & 983 & 983 & 983 & 983 \\
\hline
\end{tabular}

Notes: In columns 1-5, the dependent variable is the log of total acts of mismanagement, and in columns 6-10 the dependent variable is the log of total acts of corruption. In addition to the interaction terms presented in the table, each regression controls for the direct effect, the controls presented in 2, as well as state, lottery, service order fixed effects. Robust standard errors are reported in brackets, $+\mathrm{p}<0.10, * \mathrm{p}<0.05$. 